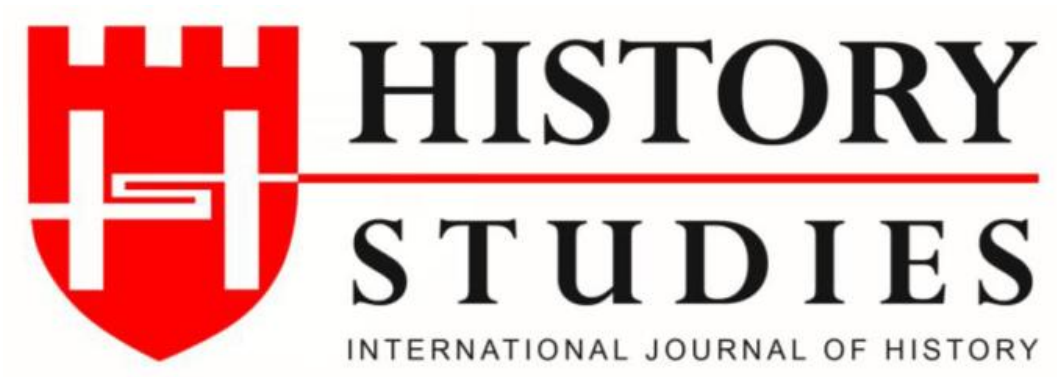

ISSN: 13094173 (Online) 1309 - 4688 (Print)

Volume 11 Issue 1, p. 403-428, February 2019

DOI: $10.9737 /$ hist.2019.723

Makalenin Geliş Tarihi: 2.01.2019 - Kabul Tarihi:31.01.2019

\title{
İsyan İkliminde Kadim Nizamı İhya Etmek: 1821 Rum İsyanı Akabinde Yapılan Eflak ve Boğdan İdarî Düzenlemeleri
} Reviving the Old Order in the Environment of Rebellion: Administrative Arrangements of Moldavia and Wallachia in the Aftermath of the 1821 Greek Rebellion

\author{
Dr. Feyzullah UYANIK \\ ORCID No: 0000-0002-7779-4350 \\ Trakya Üniversitesi Edebiyat Fakültesi Tarih Bölümü
}

\begin{abstract}
Öz: 1821 Rum İsyanı, Balkanlardaki Osmanlı varlığı açısından önemli bir kırılma noktasıdır. Aynı zamanda Eflak ve Boğdan'daki idari düzen üzerinde de kayda değer neticeleri vardır. Bu makalede, Osmanlı Devleti'nin Eflak ve Boğdan'dan Rum voyvodaları tasfiye etmesi ve yeni yönetim düzeninin oluşturulması sürecindeki politik tutumu ele alınmaktadır. Yönetimi devralan Romen voyvodaların ilk idari tasarrufları ve bu kapsamda 1821 Rum İsyanı'ndan kaynaklanan olumsuz koşulları ortadan kaldırmak üzere geliştirdikleri pratikler, incelemeye konu olan diğer hususlar arasındadır.
\end{abstract}

Anahtar Kelimeler: Eflak, Boğdan, 1821 Rum İsyanı, Osmanlı Devleti.

\begin{abstract}
The Greek Rebellion of 1821 is an important breaking point for the Ottoman presence in the Balkans. At the same time, there are significant consequences on the administrative organization in Moldavia and Wallachia. In this article, the political attitude of the Ottoman Empire in the process of liquidation of the Greek hospodars from Moldavia and Wallachia and the formation of the new administrative organization are discussed. The first administrative actions of the Romanian hospodars who took over the administration and the practices they developed to end the negative conditions arising from the 1821 Greek Rebellion are among the other issues that are subject to review.
\end{abstract}

Keywords: Wallachia, Moldavia, 1821 Greek Revolt, Ottoman Empire.

\section{Giriş}

Geniş ve kozmopolit bir coğrafyada hüküm süren Osmanlı Devleti'nin asırlar boyunca devasa büyüklükteki haritayı nasıl kontrol ve denetim altında tutabildiği sorusu, modern tarih araştırmalarının üzerinde yoğunlaştığı önemli problem alanlarından birini teşkil etmektedir. Bu yöndeki arayışların neticesinde üretilen cevaba göre Osmanlı Devleti, taşra idari yapılanmasında yerel koşulları/talepleri dikkate alarak çok yönlü düşünme ve buna paralel olarak geliştirdiği siyasi stratejiye dayanan esnek ve katılımcı bir yönetim düzeni kurduğu için merkeze uzak vilayetlerde hâkimiyetini sürdürmeyi başarabilmiştir. Osmanlı idari düzeniyle ilgili varılan bu genel yargının ne ölçüde gerçekliği yansıttığını sorgulamak için zamanın ihtiyaçlarına göre alt birimlerde uygulanan idari tasarrufları incelemek gerekmektedir. Yeni koşullar doğrultusunda revize edilebilen Osmanlı yönetim sisteminden bir kesit sunmak üzere, 1821 Rum İsyanı akabinde Eflak ve Boğdan'daki iktidarın el değiştirmesi sürecinde geliştirilen pratiklerin bu makale kapsamında incelenmesi hedeflenmiştir. 
Öncelikle Osmanlı Devleti ile Eflak ve Boğdan arasında kurulan tabi-metbu ilişkilerinin ana hatlarına değinmek, makaleye konu edilen hadiselerin anlaşılmasına yardımcı olacaktır. Batı Anadolu'da küçük bir uç beyliği olarak siyasi varlık göstermeye başlayan Osmanlı Devleti'nin stratejik bir anlayış doğrultusunda belirlenen fetih hareketlerinin hedefinde Tuna'nın kuzeyi de bulunacaktır. ${ }^{1}$ XIV. yüzyılın son çeyreğinde Eflak ile irtibata geçen Osmanlı Devleti, I. Süleyman'ın (Kanunî) Boğdan seferiyle birlikte (1538) Eflak ve Boğdan'1 tam anlamıyla himayesi altına almıştır. ${ }^{2}$ Eflak ve Boğdan Beylikleri, temelini İslam hukukundan alan darü'l-ahd prensibi doğrultusunda Osmanlı Devleti'ne bağlanmışs ve bu tabiiyetin sembolü olarak senede bir defa haraç ödemeyi taahhüt etmişlerdir. ${ }^{4}$ Ayrıca, Eflak ve Boğdan divanlarında ${ }^{5}$ yapılan seçimle ortaya çıkan iradeye, geçici barış halini sürdüren darü'lahd uygulamasının gereği olarak Osmanlı Devleti saygılı davranmış ve voyvodalar Romenler arasından tayin edilmiştir. 1683 Viyana kuşatmasındaki bozgunun ve akabinde vuku bulan uzun savaşlardaki müteselsil başarısızlıkların 1699 Karlofça Antlaşması'yla tescillenmesi, Balkanlardaki Osmanlı hâkimiyeti için başka aktörlerin de etkin olmaya başladığı yeni bir süreci başlatmıştır. Karlofça Antlaşması'nın şartları gereği, Erdel ve Macaristan'ın tamamı Habsburg İmparatorluğu'na dahil edilerek Eflak ve Boğdan etrafındaki güvenlik çemberi kırılmıştır. ${ }^{6}$ Çar I. Petro'nun liderliğinde önemli atılımları gerçekleştiren Rusya da Lehistan'da avantajlı bir konum elde ederek Balkanlardaki Osmanlı varlığı için etkin bir tehdit unsuru olarak sivrilmiştir. ${ }^{7}$ XVII. yüzyılın sonlarında şekillenen bu siyasi atmosferde, Eflak ve Boğdan voyvodaları da bağımsız ve müstakil bir devlet kurmak için ittifak arayışlarına girmişlerdir. Eflak Voyvodası Konstantin Brinkoveanu, 1698 yılında Çar I. Petro ile temas kurmuş, müşterek Romen-Rus askerî harekâtını teklif ederek Osmanlı boyunduruğundan kurtulmayı planlamıştı. Osmanlı Devleti, Brinkoveanu'nun, Rusya ile gizlilik içerisinde sürdürdügü bu yöndeki faaliyetlerinden ancak 1714 yılında haberdar olmuş ve dört oğluyla

\footnotetext{
${ }^{1}$ Feridun M. Emecen, “Osmanlıların Tuna'nın Kuzeyine Yönelik İlgileri XVI. Asırda Erdel Örneği”, Osmanlı Klasik Çağında Siyaset, İstanbul 2009, s. 221-238; Tayyib Gökbilgin, "XVI. Asır Ortalarında Osmanlı Devletinin Tuna Havzası ve Akdeniz Siyasetleri, Bunlar Arasındaki Alâka ve İrtibat, Muhtelif Veçheleri”, Ankara Üniversitesi Dil ve Tarih-Coğrafya Fakültesi Dergisi, XIII/4, Ankara 1955, s. 63-77.

${ }^{2}$ Mihail Guboğlu, “Kanuni Sultan Süleyman'ın Boğdan Seferi ve Zaferi (1538 M. 945 H.)”, Belleten (ayrı basım), L/198, Ankara 1987, s. 786-787;

3 İslam hukukuna göre darü'l-ahd kapsamındaki topraklarla ilgili uygulamalar için bkz. Halil İnalcık, "Dār al"Ahd", The Encyclopaedia of Islam (EI), II, Leiden: E. J. Brill, 1991, s. 116; Ahmet Özel, "Dârüssulh", Türkiye Diyanet Vakfi Íslam Ansiklopedisi (DIA), IX, İstanbul 1994, s. 5-6; Osmanlı barış sisteminin geleneksel ve hukuki dayanakları hakkında genel değerlendirme için bkz. Viorel Panaite, "Notes on the Islamic-Ottoman Law of Peace", Revue des Études sud-est Européennes, XLI/1-4, Bucureşti 2003, s. 191-206.

${ }^{4}$ Viorel Panaite, "Osmanlı Barışı Sisteminde Haraç veren Voyvodalıklar: Eflak ve Boğdan Meselesi”, Kemal Karpat'a Armağan: Karpat Koca Bir Çınar, (der. Kaan Durukan, Robert W. Zens, Akile Zorlu Durukan), (çev. İlknur Güzel), İstanbul 2014, s. 34-70; Feridun Emecen, "Haracgüzar", DİA, XVI, İstanbul 1997, 90-92.

${ }^{5}$ Birebir aynı olmasa da Osmanlı Devleti'ndeki Divan-1 Hümayun'a benzer birer divan teşkilatı Eflak ve Boğdan'da bulunmaktaydı. Resmi kayıtlarda "Sfatul Domnesc" adıyla anılan bu kurum için Eflak ve Boğdan'da Osmanlı hâkimiyetinin yerleşmesiyle birlikte XVI. yüzyılın sonlarından itibaren "Divan" tabiri daha yaygın olarak kullanılmaya başlanmıştır. Nicolae Stoicescu, Sfatul Domnesc și marii Dregători din Țara Românească și Moldova (sec. XIV-XV), Bucureşti 1968, s. 13-16; Kurt W. Treptor, Marcel Popa, Historical Dictioanry of Romania, London 2000, s. 88-90.

${ }^{6}$ Abdülkadir Özcan, "Karlofça Antlaşması”, DİA, XXIV, İstanbul 2001, s. 504-507.

${ }^{7}$ I. Petro'nun Rusya'yı büyük devletler arasına dahil etmek için yürüttüğ̈̈ reform çalışmaları hakkında bkz. Evgenii V. Anisimov, The Reforms of Peter the Great: Progress Through Coercion in Russia, (translate John T. Alexander), M.E. Sharpe; Armonk, New York; London 1993; Orijinal metne ulaşılamadığı için kendisine ait olup olmadığ yönünde haklı itirazlar bulunan bir vasiyetnamenin, güneye yayılma siyasetinin ve Balkan politikalarının rehberi olduğu varsayılmaktadır, bkz. Boris Mouravieff, Deli Petro 'nun Vasiyetnamesi, çev, Refik Özdek, İstanbul 1966.
} 
birlikte kendisini idam etmişti. ${ }^{8}$ Karlofça Antlaşması'nın müzakereleriyle birlikte Osmanlı bürokrasisinde yükselen Fenerli Rum voyvodaların Eflak'taki hâkimiyeti Brinkoveanu'nun yok edilmesinden sonra başlamıştır.

Boğdan'da ise Fenerli voyvodalar devri Eflak'tan önce açılmıştı. İsveç Kralı XII. Şarl'ın Poltova Savaşı'nda (1709) Rusya karşısında mağlup olarak Osmanlı topraklarına sığınması ile başlayan süreç, 1711 Prut Savaşı'nı tetiklemekle kalmayıp Eflak ve Boğdan yönetimlerindeki idareci profilini bütünüyle değiştirecek gelişmelere müncer oldu. Boğdan Voyvodası Dimitri Kantemir, 1711 Prut Savaşı öncesinde Lutsk şehrinde ${ }^{9}$ vardı̆̆ı uzlaşı gereğince tabi olduğu Osmanlı Devleti'ne karşı müşterek Rus-Romen işbirliğinin gerçekleşmesini sağladı. ${ }^{10}$ Aynı zamanda entelektüel birikimiyle de devre damgasını vurmuş olan Dimitri Kantemir, Boğdan Osmanlı hâkimiyeti altına alındığından beri geçerli olan ve temel dayanağını darü'l-ahd prensibinden alan "Dosta dost, düşmana düşman" ilkesini tam aksi istikamette işletmiş oldu. Brinkoveanu'nun önceki satırlarda temas edilen gizli faaliyetleri ve Dimitri Kantemir'in Rusya ile geliştirdiği münasebetler, Osmanlı merkezî hükümetinin nazarında Romen voyvodaların devlete sadık birer idareci olma vasıflarını yitirmeleri için yeterli gerekçelerdi. Bu politik ve askeri gelişmeler muvacehesinde, Eflak ve Boğdan'ın geleceği 1821 y1lına kadar Memleketeyn divanlarında yapılan seçimle belirlenen Romen beyler yerine, doğrudan Babıali tarafından atamaları yapılan Fenerli Rum voyvodalara emanet edildi. ${ }^{11}$ Eflak ve Boğdan'daki Fenerli yönetici zümreden, halkın refah seviyesini yükseltmeleri, Osmanlı Devleti'ne yakışır bir idareci gibi ölçülü davranmaları ve devlet menfaatleriyle bağdaşan kamu hizmetlerini üretmeleri beklenmekteydi. ${ }^{12}$ Osmanlı Devleti bu idari tasarruf kapsamında, sadakatlerini ispatlamış olan Fenerlileri Eflak ve Boğdan'da hakim kılarak bölgede etkinliğini artıran diğer aktörlerle işbirliği yapma tehlikesi olan Romenleri bertaraf etmeyi planlamış olmalıdır. Her ne kadar geç tarihli olsa da III. Selim'in bir hatt-1 hümayununa yansıyan "Hakîkat Boğdan'ın re 'âyâsl ve boyarlart ${ }^{13}$ şimdi Moskov gibidir. Onlart idâre ve ra 'iyyet hükmüne idhâl etmeğe muktedir kim vardır? ${ }^{14 "}$ ifadeleri, bu gerçekliği doğrulamakla kalmayıp, Osmanlı merkezî

\footnotetext{
${ }^{8}$ Adrian Tertecel, "Eflâk Prensi Konstantin Brinkoveanu'nun Rus Çarı Deli Petro'ya 1698'de Gönderdiği Bir Mektupta Bulunan Osmanlı İmparatorluğuna Karşı Müşterek Bir Rus-Romen Askerî Harekâtının Plânı”, Türk Dünyası Tarih Dergisi, Sayı 118, İstanbul (Ekim) 1996, s. 7-14.

${ }^{9}$ Lutsk Şehri, günümüzde Ukrayna'nın Kuzeyi’nde bulunmaktadır.

${ }^{10}$ Bogdan Mihail, "The Russian Modernist Influences in the Danubian Principalities", From Kaftan to Redingote: The Romanian World from Exotism to Modernism (17th-20th Centuries), s. 83; Bu dönemle ilgili bir değerlendirme için bkz. Münir Aktepe, "Prut Seferi ile İlgilı Ba'zı Belgeler”, Tarih Dergisi, XIV, İstanbul 1984, s. 19-54; Mustafa Ali Mehmet, "Romen Vekâyinâmelerine Göre Baltacı Mehmed Paşa'nın Prut Seferi (1711)", Türk Kültürü Araştırmaları İbrahim Kafesoğlu'nun Hatırasına Armağan, XXIIII/1-2, Ankara 1985, s. 427-436.

${ }^{11}$ Fenerlilerin Eflak ve Boğdan'daki etkinliklerine ve Osmanlı bürokratik hiyerarşisi içerisindeki konumlarında dair değerlendirmelerin yer aldığı bazı çalışmalar için bkz. Christine M. Philliou, Biography of an Empire: Governing Ottomans in an Age of Revolution, London 2011; Radu Florescu,"The Fanariot Regime in the Danubian Principalities”, Balkan Studies, IX, 1968, s. 301-318; Zeynep Sözen, Fenerli Beyler 110 Yllın Öyküsü (1711-1821), İstanbul 2000.

${ }^{12}$ Voyvodalardan Osmanlı Devleti'nin beklentileri şu ibarelerle formüle edilmişti: "rabt-l zabt-ı memleket ve temîn$i$ terfîh-i fukarâ-yı ra 'iyyette ihtimâm ve dikkat ve şân-ı şevket-i saltanât-ı seniyyeme muvâfik harekât-ı sencîde ve hidemât-ı pesendîde izhârına bezl-i tâb ve tâkat eylemen” şeklindeydi. Devlet Arşivleri Başkanlığı (DAB), Düvel-i Ecnebiye Defterleri (A.DVN.DVE.d), nr. 77-1, s. 43.

${ }^{13}$ Eflak ve Boğdan'da, boyar ismiyle bilinen asilzadeler grubu, kendi içlerinde büyük boyarlar ve Marsil denilen diğer grup ise küçük boyarlar olmak üzere iki alt sınıfa bölünmüşlerdir. En yüksek dereceli yöneticiler büyük boyarlar arasından seçilerek göreve getirilirdi. Asilzade grubu her iki memlekette de çok geniş imtiyazlara sahipti. Mehmed Şevki, "Memleketeyn-i Müctemiateyn: Eflak-Boğdan”, Mecmû'a-i Fünûn, IV/35, İstanbul 1283, s. 57. Boyarların etnik menşeinin Kumanlardan geldiği öne sürülmüştür. İddiaya göre, XIV.-XV. asırlarda Kumanca konuşan bu topluluk zamanla azınlık kaldıkları için Romenler içerisine karışarak Romenleşmiş̧lerdi bkz. Zeki Velidi Togan, Umumi Türk Tarihine Giriş, İstanbul 1981, s. 165-166.

${ }^{14}$ DAB, Hatt-ı Hümâyûn (HAT.), nr. 58611.
} 
hükümetinin bölgedeki otoritesini güçlendirmeyi hedeflediğini somutlaştırması bakımından da kayda değerdir.

1774 Küçük Kaynarca Antlaşması'yla Rusya'ya Eflak ve Boğdan yönetimlerindeki aksaklıkları gözlemleme ve Babıali'ye bildirme hakkı tanınması ${ }^{15}$ ve 1802 fermanıyla ${ }^{16}$ bu tavizin pekiştirilmesiyle birlikte voyvoda atamaları daha hassas ve nazik bir konu olmuştur. Yeni koşullar doğrultusunda oluşan siyasi atmosferde, esasında Osmanlı Devleti'nin Fenerli voyvodalar arasından da uygun adayı tespit etmekte güçlük çektiği anlaşılmaktadır. Babıali tarafındaki güvensizlik problemi, çok katmanlı bir dünyaya ait olan Fenerlilerin Rusya ve Avrupa'daki güçlü bağlantılarından kaynaklanmaktaydı. Bu nedenle, 1802 yılında yapılacak atamalarda yerli boyarlar arasından bir voyvoda tayini, Babıali'de gündeme getirilmişse de Reisülküttap Efendi'nin Rusya ile devam eden dostane münasebetlerin bu hamleden büyük zarar göreceği yönündeki endişeleri ve ikazları dolayısıyla fiiliyata geçirilmemiştir. ${ }^{17}$ Ancak Rusya'nın tavassutuyla voyvodalığa getirilen Konstantin İpsilanti'nin ${ }^{18} 1804$ yılında başlayan Sırp İsyanları'nı Rusya'nın yönlendirmesiyle el altından desteklemesi ve Fransa'ya karşı Rusya ile İngiltere arasında kurulmuş ittifak cephesini kırmayı hedefleyen Sebastiani'ın teşvikleriyle 1802 fermanındaki taahhüde aykırı olacak şekilde Eflak ve Boğdan voyvodalarının yedi yıllık görev süreleri dolmadan azledilmeleri, 1806-1812 Osmanl1-Rus Savaşı'nı tetikleyecek bir boyut kazandığında devrin vakanüvisi Mütercim Asım Efendi kalemini sakınmayarak "la în-i bî-dîn ve hâ'in-i habâset-âyîn" ifadeleriyle Konstantin İpsilanti özelinde Rum voyvodalardan duyulan rahatsızlığ 1 dile getirecektir. ${ }^{19}$

1802 yılındaki politik koşullardan dolayı Romen boyarların voyvoda tayin edilmesi yönündeki yarım kalmış teşebbüs, ancak 1821 Rum İsyanı akabinde tamamlanacaktır. Bilindiği üzere 1814'te Hocabey'de Filik-i Eterya cemiyetinin teşkilatlanmasıyla birlikte, Balkanlardaki Rum ayrılıkçı faaliyeti daha sistemli ve organize hale geldi. Rusya'yla kolay bir şekilde irtibat kurulabilecek stratejik bir üs olarak değerlendirildiği için 1821 Rum İsyanı'nın kaderi Eflak ve Boğdan'la kesişti. ${ }^{20}$ Diğer yandan Eflak ve Boğdan yönetimlerinin Fenerli Rumlar elinde olması, Filik-i Eterya yöneticileri için bölgeyi cazip bir seçenek haline getirdi. Filik-i Eterya yönetimi, başlatılacak olan başkaldırıya Eflak ve Boğdan voyvodalarını dahil etmeyi, eğer bu başarılamazsa mevcut voyvodalar yönetimden uzaklaștırılarak amaçlarına hizmet edecek Fenerli Rumlar arasından yeni voyvodaların belirlenmesini kararlaştırdılar. ${ }^{21} \mathrm{Bu}$

\footnotetext{
${ }^{15}$ Osman Köse, 1774 Küçük Kaynarca Andlaşmasl, Ankara 2006, s. 115.

${ }^{16} 1802$ fermanı kapsamında, 1174 Küçük Kaynarca Antlaşması'yla Eflak ve Boğdan konusunda Rusya'ya verilen tavizler genişletilmiştir. Mülki, idari, adli, sosyal ve ticari konuları kapsayan ve 1802 fermanıyla yürürlüğe sokulan düzenlemeler için bkz. DAB, Bab-ı Asafi Amedi Kalemi Dosyaları (A.\{AMD.), nr. 47-11; DAB, A.DVN.DVE.d., nr. 81-5, s. 107.

${ }^{17} \mathrm{DAB}, H A T .$, nr. 5582.

${ }^{18} \mathrm{DAB}$, HAT., nr. 5428.

${ }_{19}$ Mütercim Ahmed Asım Efendi, Assm Efendi Tarihi (Osmanll Tarihi 1218-1224/1804-1809 İnceleme-Metin), (haz. Ziya Yılmazer), I, İstanbul 2015, s. 446; Konstantin İpsilanti'nin Sırp İsyanlarında yer alış1 ve bu isyanların detayı için bkz. Selim Aslantaş, Osmanlıda Sırp İsyanları 19. Yüzyılın Şafağında Balkanlar, İstanbul 2007, s. 96 vd.

${ }^{20}$ Rumların Himayesi ve Eflak-Buğdan'ın Tahliyesi Hakkında, İstanbul Büyükşehir Belediyesi Atatürk Kitaplı̆̆ı, nr. 61, vr. 2b; Yunan Fesâdına Dâir Bazı Fıkarât-ı Târîhiyye, Fatih Millet Kütüphanesi, Ali Emiri Tarih, nr. 669, s. 3-5. Rum tacirlerden Emmanuel Xsanthos, Athanasios Tsakaloff ve Nikolas Skufas Filik-i Eterya'y teşkilatlandırmışlardı. Bu üç kurucu lider hakkında muhtasar biyografik malumat için için bkz. Vasilis Panagiotopoulos, "The Filiki Eteria (Society of Friends) Organizational Preconditions of National War of Indipendence", The Greek Revolution of 1821: A European Event, (ed. Petros Pizanias), İstanbul 2011, s. 106-108.

${ }^{21}$ Melik Bey, Tarih-i Mora, Türk Tarih Kurumu Kütüphanesi Yazmaları (TTK), nr. Y/30, s. 28; George Demetrios Frangos, The Philike Etaireia, 1814-1821: A Social and Historical Analysis, Colombia Universty, (Unpublished) Phd Thesis, 1971, s. 96-100; Georges Castellan, Balkanların Tarihi (14.-20. Yüzyll), (terc. Ayşegül YaramanBaşbuğu), İstanbul 1993, s. 270-271; Ahmed Cevdet Paşa, Tarih-i Cevdet, XI, İstanbul 1309, s. 85, 91, 109-112;
}

HISTORY

STUDIES

406

Volume 11

Issue 1

February

2019 
esnada sağlık durumu kötüleşmiş olan Eflak Voyvodası Aleko Sutu, Eterya'nın planına iştirak etmediği için tesadüf eseri (!) Tudor Vlademirescu'nun harekete geçeceği gece, kaynaklardan sebebi tam olarak saptanamayan bir şekilde hayatını kaybetti. ${ }^{22}$ Boğdan Voyvodası Mihail Sutu ise, isyanın lideri Aleksandr İpsilanti'yi Boğdan topraklarında karşılayarak elinden gelen yardımı gösterdi. ${ }^{23}$ Osmanlı Devleti, Aleko Bey'in ölüm haberini aldığında yerine Kallimakizade İskelert'i voyvoda tayin etti. ${ }^{24}$ Ancak Babıali, Eflak'ta gelişen isyandan dolayı İskerlet'i Bükreş'e göndermek yerine Avrupa devletlerinin elçileriyle haberleşmesini yasaklayıp Süleymaniye'de bir nevi göz hapsine aldı. Eflak’taki işlerin yürütülmesi ise yine isyancılarla irtibat ve iltisak halinde olduklarından şüphe duyulan kaymakamlara havale edildi. Aleksandr İpsilanti'nin işbirlikçisi Mihail Sutu'nun yerine kaymakam sıfatıyla Stefan Vogorides görevlendirildi. ${ }^{25}$ Tabii olarak, Eflak ve Boğdan yönetimlerinde oluşan bu olağanüstü koşulların sürdürülebilirliği söz konusu değildi.

Filik-i Eterya Rum İsyanı'nı tasarlarken, Avrupa'da meşru hükümdarlara karşı başlatılmış ihtilallerin desteklenmemesi konusunda Rus Çar'1 Aleksandr'ın ve Avusturya Dış İşleri Bakanı Metternich'in Laibach Konferası'nda prensipte anlaştığını, ${ }^{26}$ Romenlerin Rumların bağımsızlığını destekleyerek servet ve imtiyazlarını kaybetme tehlikesini bertaraf etmeyi düşünebilecekleri ihtimalini, biraz da Osmanlı Devleti'nin müdahalesinden dolayı duydukları çekinceden dolayı içerisinde bulundukları olumsuz şartları ortadan kaldırmak üzere isyana iştirak etmelerini ${ }^{27}$ hesaba katmamaları ve Osmanlı Devleti’nin olağanüstü koşulları

HISTORY STUDIES

Mihail Sutu'nun Filik-i Eterya'ya Kasım 1820'de üye olduğu literatürde kaydedilmektedir. Christine M. Philliou, Biography of an Empire: Governing Ottomans in an Age of Revolution, s. 86.

${ }^{22}$ Bâbıâli'ye boyarların Aleko'nun ölümüne dair ulaştırdıkları haberde ise kırk sekiz günden beri durumunun kötüye gittiği ve en nihayetinde "emr-i hakkın vâki olduğu” yazmaktadır (DAB, HAT., nr. 45924 A); Bükreş’te Filik-i Eterya'nın faaliyetleri ilerlemiş olduğundan, Aleko Sutu'nun ailesi voyvodanın zehirlendiğini ispat etmeye cesaret edememişlerdi. Hatta boyarlar tarafından Bâblâli'ye ulaştırılan haberlerde Aleko Sutu Bey'in eceliyle öldüğü bildirilmekteydi (Ahmed Cevdet Paşa, Tarih-i Cevdet, XI, s. 115-116); Vakanüvis Şanizade'nin anlatımına göre, Aleko Sutu'nun zehirlenmesinde Boğdan Voyvodası Mihail'in payı bulunmaktaydı. Aleko'nun öldürülmesi için doktorunu, Boğdan Voyvodası Mihail'in bazı papazlar ve itimat ettiği kimseler aracıllğıyla ulaşarak yapacağ işin dinlerine büyük bir hizmet olacağı şeklindeki aldatıcı sözlerle, ikna ettirdiğini kaydetmektedir bkz. Şânî-zâde Mehmed 'Atâ'ullah Efendi, Şânî-zâde Târihi (1223-1237/1808-1821), II, İstanbul 2008, s. 1022-1023; Literatürde de Aleko Sutu'nun zehirlenerek öldürüldüğ̈̈ kaydedilmektedir. Radu R. Florescu, The Struggle Aganist Russia in the Romanian Principalities 1821-1854, Iaşi 1997, s. 101; R. W. Seton-Watson, A History of the Roumanians from Roman Times to the Completion of Unity, Archon Books 1963, s. 194.

${ }^{23}$ DAB, Bab-ı Asafi Divân-ı Hümâyûn Kalemi Dosyaları (A.\{DVN.), nr. 2509-13; DAB, Bab-ı Asafi Mektubi Kalemi Dosyalart (A.\{MKT.), nr. 1583-61; A.\{MKT., nr. 1582-4; A.\{MKT., nr. 1582-47; A.\{MKT., nr. 1583-4; A.\{MKT., nr. 1583-16; DAB, C.DH., nr. 45-229; Mihail Sutu, İpsilanti'nin Prut Nehri'ni geçip Yaş'a ulaşacağı yolun etrafına isyan için hazırladığı askerleri yerleştirmiştir. İpsilanti Yaş'a ulaştığında onun için bir karşılama merasimi düzenleyerek bağlılığını sunmuştur bkz. Mehmet Mansur, Rum Fetreti -Yunanistan İsyân ve Teşekkülü(Tahlil Ve Transkripsiyon), (haz. Volkan Marttin), Osmangazi Üniversitesi Sosyal Bilimler Enstitüsü, (Basılmamış) Yüksek Lisans Tezi, Eskișehir 2004, s. 2.

${ }^{24}$ İskerlet Bey'e Eflak Voyvodalığı 14 Şubat 1821 tarihinde tevcih edilmiştir bkz. DAB, Tahvil d., nr. 39, s. 230.

25 DAB, HAT., nr. 50163; HAT., nr. 459658; Ahmed Cevdet Paşa, Tarih-i Cevdet, XI, 194; Daha sonraki dönemlerde Osmanlı diplomasisinde etkin roller üstlenecek olan Vogorides'in kariyeri ve faaliyetleri için bkz. Musa Kılıç, "1821 Rum İsyanı Sonrasında Fenerlilerin Bürokraside Yeniden İstihdamlarında İki Öncü İsim: İstefanaki Vogorides ve Nikolas Aristarki”, Musa Çadırcıya Armağan/Studies Presented in Honour of Musa Çadırcl, Ankara 2012, s. 275-284.

${ }^{26}$ Barbara Jelavich, Russia and the Formation of Romanian National State 1821-1878, Cambridge 1984, s. 23-24; Eflak ve Boğdan'da başlayan Rum İhtilali'ni desteklemediklerini Rus Çarı Aleksandr (DAB, A.\{DVN., nr. 2509-13; DAB, A.\{MKT., nr. 1583-61) ve Avusturya Dıș İșleri Bakanı Metternich (DAB, HAT., nr. 45465 G; HAT., nr. 45465 D) resmi kanaldan Babiali’ye bildirmișlerdir.

${ }^{27}$ Tudor Vladimirescu önderliğindeki Romenler, Osmanlı Devleti'nin muhtemel müdahalesinden çekinerek Rumların bağımsızlık hareketine katkı sunmaktan ziyade bölgedeki müesses nizamın bozulmasından kaynaklanan olumsuz koşulları iyileştirmeyi hedeflediklerini Osmanlı Devleti'ne iletmişler ancak itibar edilmemişti bkz. DAB, 
sonlandıracak başarılı müdahalesi nedeniyle hedeflerine ulaşamamışlardı. ${ }^{28} \mathrm{Bu}$ şartlar altında, Boğdan Voyvodası Mihail Sutu'nun Rusya tarafına firarı ve Rusya'nın voyvoda atanması konusundaki 1srarları, Eflak ve Boğdan'ın olası bir Rus müdahalesinden dolayı işgal altında kalabileceği endişesini tetiklediğinden dolayı Avrupa elçileriyle görüştüğü bahane edilerek Bolu'ya sürülen Eflak Voyvodası İskerlet'in zehirlenerek ortadan kaldırılmasıla birlikte Memleketeyn'e yeni voyvodaların gönderilmesi hususu gündeme gelmiştir. ${ }^{29}$ Rum İsyanı tamamen sonlandırılmadan, Eflak ve Boğdan voyvodalarını Rumlar arasından tayin etmenin imkansız olduğu gerekçe gösterilerek karar verme sürecinde Rusya'ya karşı oyalayıcı bir tutum sergilenmiştir. ${ }^{30}$ Babıali, her iki memleketin voyvodasız kalması üzerine, Eflak ve Boğdan yönetimlerini emanet edeceği adaylarla ilgili çalışmalarını ve 1711'den sonra ortaya çıkıp 1774 Küçük Kaynarca Antlaşması'yla yeni bir ivme kazanan yabancı etkinliğini gözden geçirecek çalışmaları başlatmıştır.

\section{Fenerliler öncesi döneme (kadim nizama) dönüş için arayışlar ve ön hazırlıklar}

Rumların Osmanlı hâkimiyetinden kurtulma yönündeki istekleri Eflak ve Boğdan'da başlayan isyanla birlikte aşikar hale geldiğinden, Osmanlı Devleti'nin bölgedeki yönetimle ilgili bazı koşulları gözden geçireceği Memleketeyn'de bilinmekteydi. Yeni düzenin kurulma sürecini sağlıklı bir şekilde yürütebilmek adına Eflak ve Boğdan yönetiminde söz sahibi olan boyarlar, Bâbıâli'ye karşı uzlaşmacı ve yapıcı bir tutum takınarak irtibat kurma eğiliminde oldular. ${ }^{31}$ Boyarlar bu amaç doğrultusunda, öncelikle Osmanlı Devleti'ne sadakatle bağlı olduklarından ötürü Rumlardan farklı görülmeleri gerektiğini anlatmak ve kurulacak yeni düzenle ilgili önerilerini II. Mahmud'a bildirmek için Silistre Valisi Selim Paşa’ya müracaat ettiler. $^{32}$

İstanbul'da ise kapalı kapılar ardında Memleketeyn'in durumu ve tayin edilecek voyvodalarla ilgili tasarılar geliştirilmekte ve bu yöndeki çalışmalar yabancı elçiler tarafından dikkatle izlenmekteydi. ${ }^{33}$ İsyan ortaya çıktığında, Eflak ve Boğdan boyarları asilerin karşısında durarak Osmanlı Devleti’ne sadakatlerini göstermekten imtina etmişlerdi. Bu sebeple, yerli

HAT., nr. 45963 C; Keith Hitchins, A Concise History of Romania, New York 2014, s. 79; R. W. Seton-Watson, A History of the Roumanians from Roman Times to the Completion of Unity, s. 197-198.

${ }^{28}$ İsyana Osmanlı kamuoyunun ilk tepkisi ve alınması planlanan önlemler için bkz. Ali Fuat Örenç, Balkanlarda İlk Dram Unuttuğumuz Mora Türkleri ve Eyaletten Bağımsızlı̆̆a Yunanistan, İstanbul 2011, s. 49-52; Osmanlı Devleti’nin aldığı önlemlerle ilgili bir diğer çalışma için bkz. Filiz Yaşar, "Yunan İsyanında Osmanlının Rumeli'de ve Anadolu'da Aldığ 1 Güvenlik Önlemleri: Tedâbîr-i Osmâniyye”, Hacettepe Üniversitesi Edebiyat Fakültesi Dergisi, XXXII/2, Ankara 2015 s. 277-297; Rum İsyanı'nın Eflak ve Boğdan'daki serüvenini Osmanlı arşiv belgeleri doğrultusunda inceleyen bir çalışma için bkz. Yücel Özkaya, "1821 Yunan (Eflak-Buğdan) İsyanları ve Avrupalıların İsyan Karşısındaki Tutumları”, Üçüncü Askeri Tarih Semineri Bildiriler; Tarih Boyunca Türk-Yunan İlişkileri (20 Temmuz 1974'e Kadar), Ankara 1986, s. 114-132.

${ }^{29} \mathrm{DAB}$, HAT., nr. 45655; İskerlet'in II. Mahmud'un gizli talimatıyla zehirlenerek ortadan kaldırılması için bkz. (DAB, HAT., nr. 45611).

${ }^{30}$ Nikolae Jorga, Osmanlı İmparatorluğu Tarihi (1774-1912), V, (terc. Nilüfer Epçeli), İstanbul 2009, s. 227.

${ }^{31}$ R. W. Seton-Watson, A History of the Roumanians from Roman Times to the Completion of Unity, s. 200-201.

${ }^{32}$ Boğdan'dan taleplerini iletmek üzere aralarında Fenerlilerden sonra yerli ilk voyvoda olarak karşımıza çıkacak olan Logofet Sturdza'nın da bulunduğu muteber 6 boyar, Boğdan kaymakamı Stefan tarafindan Silistre'ye gönderilmiştir (DAB, HAT., nr. 45365 E); Eflak'tan ise aralarında Büyük Vestiar Barbi Vacanisco'nun da bulunduğu 8 boyar İstanbul'a gelmek üzere yola çıkmıştı (Theophilus C. Prousis, Lord Strangford at the Sublime Porte (1821): The Eastern Crisis, II, İstanbul 2012, s. 115); Stratford Canning bu raporunda Eflak'tan 8 boyar geldiğini kaydetse de Eflak ve Boğdan'da kurulan yeni düzeni ve voyvodaları konu alan raporunda Eflak'tan 7 boyar geldiğini belirterek daha önceden verdiği bilgiyi düzeltmiştir bkz.Theophilus C. Prousis, Lord Strangford..., II, s. 127.

${ }^{33}$ Stratford Canning, yapılacak olan yeni atamaları konu alan bir raporunda yerli boyarlardan voyvoda tayin edilmesi seçeneğinin Halet Efendi tarafından değerlendirildiğini kaydetmektedir bkz. Theophilus C. Prousis, Lord Strangford at the Sublime Porte (1821): The Eastern Crisis, II, s. 80. 
boyarlardan voyvoda tayin edilse bile kendileri Bâbıâli'de "müfsid mizâc" olarak görülmekte ve idarede oldukları dönemde pek çok fesada sebebiyet verdiklerinin altı çizilmekteydi. Ancak görünürde Osmanlı Devleti'ne itaat ve bağlılıklarını sunduklarından, tamamı affedilerek eskiden beri geçerli olan nizam ve ayrıcalıklarına dokunulmayacağı bildirilmeliydi. Zaten bölgede güvenlik ve asayiş tam anlamıyla sağlanmadan, firari Mihail Sutu, Aleksandr İpsilanti ve diğer elebaşları Osmanlı Devleti'ne iade edilmeden, voyvoda tayini mahzurlu görülmekteydi. Bu süreçte Fenerlilere artık itimadı kalmayan Osmanlı Devleti'nin Eflak ve Boğdan'a Hristiyan bir voyvoda yerine birer Müslüman memur veya diğer tebaadan görevliler göndermesi, Rusya'nın mevcut antlaşmalara dayanarak şiddetli itirazlarına konu olacağından yerli boyarlarla irtibat kurulması en uygun seçenek olarak değerlendirilmekteydi. ${ }^{34}$

Bâbıâli, bu süreçte yerli boyarlardan tayin edilen voyvodaların Prut Savaşı (1711) esnasında Osmanlı Devleti'ne karşı Rusya ile işbirliği yaptıklarını ve yeniden yerli boyarlardan tayin edilecek voyvodanın yine buna benzer bir ihanet teşebbüsünde bulunmasını güçlü bir ihtimal olarak değerlendirmekteydi. Bununla birlikte, Osmanlı Devleti'ne kendilerini beğendirmek için en azından 5-10 sene sadakatle hizmet edecekleri düşünüldüğünden Bâbıâli, Eflak ve Boğdan'a yerli boyarlardan voyvoda atanmasına sıcak bakmaktaydı. Böylelikle Eflak ve Boğdan yerli boyarlarından " $m \hat{u}$ 'teber" birkaç boyarın İstanbul'a getirtilmesi istenmişti. ${ }^{35}$ Silistre Valisi Mehmed Selim Paşa, boyarların görüş ve önerilerini Bâbıâli'ye ulaştırmaları için gerekli yazışmaları yaparak nihayetinde İstanbul'a kabul edilmelerini sağlayan izinleri çıkarmıştır. İstanbul'da reisülküttabın Beylerbeyi'ndeki konağında ${ }^{36}$ boyarlar talep ve önerilerini Osmanlı Devleti'ne bildirmişlerdir. Boyarları dikkat ve ciddiyetle dinleyen Osmanlı yönetiminin beklentisi, yapılacak yeni düzenlemelerin Rusya ile geçerliliği devam eden antlaşmalara aykırılık içermemesi ve bölgede Osmanlı Devleti'nin menfaatlerinin tam anlamıyla güvence altına alınmasını kapsamaktayd ${ }^{37}$

Boyarlarla yapılan mülakatı Stratford Canning'de dikkatle takip etmekteydi. Zahire Nazırı

Ali Bey ile yakın ve güvenilir bir dostluk kurduğunu kaydeden Canning, yapılacak düzenlemelerle ilgili Ali Bey'den ilginç detaylar öğrendiğini yazmaktaydı. Bu raporunun içeriği, aşağıdaki satırlarda Osmanlı arşiv kayıtlarına göre detaylandırılan konuların özeti mahiyetindedir. $^{38}$

Boyarların talepleri, görüş ve önerileri İstanbul'da Türkçeye aktarılarak II. Mahmud'a ve Bâbıâli'deki yetkili birimlere gönderilmiştir. Boyarların kaleme aldıkları önerilerden tespit edebildiğimiz kadarıyla, en dikkat çekici olanlardan biri Vornik Nikolay Golescu'ya ${ }^{39}$ aittir. Bâbıâli nezdinde de muteber kabul edilen Nikolay Golescu'nun kapsamlı raporu, Eflak'ta Rum İsyanı'na zemin hazırlayan gelişmeler, Eflak'taki yönetim sisteminin bozulması ve yerli boyarlara devredilecek olan yeni yönetimin ihdası noktasında görüş ve önerileri içermektedir.

Nikolay Golescu'ya göre Eflak'ın yönetim sistemindeki bozulmanın temelinde Fenerli voyvodaların kanunlara ve adalete aykırı uygulamaları yatmaktaydı. Uzun zamandan beri

\footnotetext{
${ }^{34} \mathrm{DAB}, H A T .$, nr. 45341.

35 "Eflak ve Boğdan boylarlarından Moskovlu'nun hilâfı olanların içlerinden söz sâhibi ve mû 'teber ve dirâyetkâr ve sadâkat ve istikameti me'mûl olan birkaç nefer boyarların” İstanbul'a getirilmesi kararlaştırılmıştır bkz. DAB, $H A T .$, nr. 45441.

${ }^{36}$ Cevdet Paşa bu konağın ismini Yusuf Ziya Paşa yalısı olarak vermektedir. Ahmed Cevdet Paşa, Tarih-i Cevdet, XII, İstanbul 1309, s. 45.

${ }^{37}$ DAB, HAT., nr. 45591

${ }^{38}$ Theophilus C. Prousis, Lord Strangford at the Sublime Porte (1821): The Eastern Crisis, II, s. 126.

${ }^{39}$ Romen beylikleri teşkilatında Vornik, iç işleri bakanlığı görevini yürüten yüksek rütbeli boyara denirdi. Nikolay Golescu, Babıali ile irtibata geçtiğinde bu görevi sürdürmekteydi. Ayrıntı için bkz. Keith Hitchens, The Romanians 1774-1866, s. 155.
} 
Eflak'ta Rumeli tarafından sayıları oldukça fazla olan Rum papazlar, Rum, Arnavut ve Bulgar milletleri bölgeye yerleşmeye başlayarak, Eflak yönetimindeki Fenerli voyvodalar tarafından kendilerine saygınlık kazandırılmıştı. Bu yabancı unsurlar, zamanla servet edinip görkemli konaklar ve binalar inşa ederek Eflak ahalisi arasına karışıp fakir reayayı soydular. Rumlardan tayin edilen Eflak voyvodaları, beraberlerinde çok sayıda Rum'u getirdiler ve bunlar Bükreş’te kalarak doğru yoldan saptılar. Voyvoda değişikliklerinde yeni gelen voyvodalar, bölgeye seleflerinin yerleştirdiği Rumlara güvenerek önemli makamlara tayin ettiler. Yüksek meblağlarda gelirler tahsis ederek yerli Eflak boyarlarını devre dışı bıraktılar. Bölgeye gelen voyvodalara rüşvet ödeyerek yerlerini sağlamlaştırıp mülk ve moşye ${ }^{40}$ sahibi oldular. Ticaret ve alışveriş konularında Fenerli voyvodalar eliyle yerli reayanın aleyhine olacak şekilde kendilerine imtiyazlar bahşedilerek servet edindikleri için voyvodalarla sürdürdükleri rüşvet ilişkileri derinleşerek devam etmişti. ${ }^{41}$

Eflak'ta toplanan Rum, Arnavut ve Bulgarlar birbirleriyle görüş alış verişinde bulunup İstanbul, Mora, Yanya ve adalardaki dindaşlarıyla gizli yazışmalar yaparak Aleksandr İpsilanti için finansal kaynak oluşturdular. Bunu yaparken Eflak hazinesi için para toplanıyormuş gibi gösterip asıl emellerini gizlediler. Fenerli voyvodalarla birlikte Eflak manastırlarına tayin edilen Rum keşişler, manastırların gelirlerini amacına uygun olarak Eflak reayasının ihtiyaçlarına tahsis etmek yerine, kendi emelleri için gasp edip Aleksandr İpsilanti'nin başlatacağı ayaklanmaya maddi destek oluşturacak şekilde kullandılar. Bölgedeki isyan bastırılmı̧ gibi görünse de hala Bükreş’te İpsilanti ile iş birliği yapmış, firari Karaca Voyvoda'nın ve Mihail Sutu'nun adamı olan çok sayıda Rum vardı. Eflak Kaymakamı Kostantin Negri, Bükreş’teki tüm önemli işleri Osmanlı Devleti'ne ihanet eden voyvodaların bakiyesi olan Rumlar eliyle yürütmekteydi. Nikolay Golescu, Rumlar dağıtılmadıkları takdirde yeniden isyan çıkabilme tehlikesine dikkat çekmekteydi. Besarabya tarafına firar eden isyancıların yine bir fitne çıkarma ihtimali her daim göz önünde bulundurulmalıydı. Nikolay Golescu'ya göre Eflak'taki düzenin bozulmasının bir diğer nedeni de yabancı devletler tarafından ikame edilen konsoloslard $1 .{ }^{42}$ Fenerliler arasından tayin edilen voyvodaların tamam konsoloslarla iş birliği içerisinde olmuşlardır. Konsoloslar, Eflak'ın iç idari işleyişinde hemen her konuya karışmaktaydılar. Voyvodaların tayinlerine de müdahil olarak, istedikleri adayın göreve getirilmesi için gayret etmekteydiler. 1774 Küçük Kaynarca barışından sonra Ruscuk’ta

\footnotetext{
${ }^{40}$ Romen toprak idaresinde büyük tarım arazilerini ifade eden tabir. Bu topraklara sahip olan köylüler, "moşneni" diye isimlendirilmişlerdi. Boyarlarla aralarında herhangi bir bağ bulunmazdi.

${ }^{41} \mathrm{DAB}, H A T$., nr. 45522.

421774 Küçük Kaynarca Antlaşması akabinde açılan Eflak ve Boğdan'daki konsolosların faaliyetleriyle ilgili bazı çalışmalar için bkz. Kemal Beydilli, Büyük Friedrich ve Osmanlılar XVIII. Yüzyılda Osmanll-Prusya Munasebetleri, İstanbul 1985 s. 143-147; Demetrius Dvoichenko-Markov, "Russia and the First Accredited Diplomat in the Danubian Principalities, 1779-1808", Études Slaves et Est-Européennes, (Autumn-Winter) $1963 \mathrm{~s}$. 200-229; Osman Köse, "Balkanlarda Rus Konsolosluklarının Kuruluşu ve Faaliyetleri”, Turkish Studies/Türkoloji Dergisi, I/2, Erzincan 2006, s. 153-171; Akitsu Mayuzimi, "The Establishment of the Russian Consulates in the Danubian Principalities in the 1780s and the Ottoman Empire", Turkey\&Romania: A History of Partnership and Collaboration in The Balkans, (ed. Florentina Nitu, Cosmin Ionita, Metin Ünver vd.), İstanbul 2016, s. 287-295.
} 
ikamet ederlerken Bükreş'e taşınmaları uygun görüldüğünden beri Eflak'taki suditlerin ${ }^{43}$ sayısını artırarak halkı ifsad etmeye devam etmişlerdi. ${ }^{44}$

Niokolay Golescu'nun aksaklıkların ve bozulmanın arka planıyla ilgili anlatımından özetlediğimiz problemlerin çözümü için taleplerini Bâbıâli’ye iletmek üzere gelen boyarların önerileri, toplam 20 maddelik bir metin haline getirilerek sunulmuştur. Bu metne göre;

1. Rumlardan tayin edilen voyvodalar Eflak halkının mallarını çeşitli yolsuzluklar yaparak gasp etmiştir. Bu durumdan şikâyetçi olan veya muhalefet eden boyarlar gizlice öldürülerek veya etkisiz hale getirilerek engellendiği için durum Bâblâli'ye bildirilememiştir. Memleketeyn'i saran isyan hareketine voyvodaların katkıları ve ihanetleri aşikâr olduğundan bundan sonra Rumlardan voyvoda tayin edilmemesi.

2. Fenerlilerden artık voyvoda ve boyar tayin edilmemesi ve bu anlamda yetkinin Osmanlı Devleti'nin güvenilir bulduğu Romen boyarlara devredilmesi.

3. Fenerli voyvodalar döneminde Rum ve Arnavutlardan tayin edilen tüfenkcibaşı ve delilbaşıların artık divan efendisi ${ }^{45}$ ve baş beşlü ağasının ${ }^{46}$ ortak görüşü doğrultusunda Romen voyvoda tarafından tayin edilmesi, delilbaşı ve tüfenkcibaşıların maiyetindeki neferlerin voyvodalar ve boyarların müzakereleri sonucunda Romenler arasindan belirlenmesi. ${ }^{47}$

4. Fenerli voyvodalar, diledikleri kimseleri divan efendisi ve baş beşlü ağası tayin edebilmekteyken yerli boyarlar arasından tayin edilecek Romen voyvodanın uhdesinden bu tasarrufun alınması ve bundan sonra Osmanlı Devleti tarafindan uygun görülen kimselerin divan efendisi ve baş beşlü ağası olabilmesi, Beşlü ağasının maiyetine Eflak'ın muhafazası için verilecek Müslüman askerlerin "ehl-i ırz gürûhundan" seçilmesi ve ulufelerinin eskiden olduğu gibi ödenmesi, sayıları 2000 ve daha fazla olduğunda ödenecek fazla ulufenin voyvodanın kişisel gelirlerinden karşılanması ve Romenler arasından tayin edilen zabitlerle

${ }^{43}$ İtalyanca kökenli “suddito" kelimesinden türetilmiş "sudit” tabiriyle, Bükreş ve Yaş’taki yabancı konsolosların himayesinde ticaret ve zanaatla ilgili çalışmalarını sürdüren kimseler tarif edilirdi. Konsoloslar, belirli kaideler kapsamında Osmanlı tebaası olmayan kimseleri sudit adı altında himayeleri altına alabilmekteydi. Sudit olmayı kabul eden kimseler cizyeden muaf tutulmakta ve daha az gümrük vergisi ödemek suretiyle imtiyazli ticaret yapma imkanı kazanırlardı. Aynı zamanda bu zümreye dahil olan kimseler, yerli tacirlerle uzlaşmazlığa düştüklerinde konsolosun himayesinde tabi oldukları ülkenin yasalarına göre haklarını ararlardı. Ayrıntı için bkz. Keith Hitchens, The Romanians 1774-1866, New York 2011, s. 69-70

${ }^{44} \mathrm{DAB}, H A T$., nr. 45522; Voyvodaların konsoloslarla yakın işbirliği içerisinde olmalarının bir diğer nedeni de özellikle Rusya'nın Balkanlar ve Doğu Akdeniz'deki konsolosluk görevlerini Rumlara vermeyi bir gelenek haline getirmesinden kaynaklandığı öne sürülebilir. Yetenekli Rumlar Petersburg'a davet edilerek Rus diplomatik misyonlarında görevlendirilmek üzere hükümet destekli finansal kaynak oluşturularak yetiştirilmekte ve ardından göreve getirilmekteydiler bkz. Lucien J. Frary, "Russian Consuls and the Greek War of Independence (1821-31)" Mediterranean Historical Review, XXVIII/1, (2013), s. 47.

45 Divan Efendisi, Eflak ve Boğdan divanlarında çalışan tek Müslüman görevlidir. Voyvodanın yönetim uygulamalarını denetlemekle görevli olduğu anlaşılmaktadır (Eflak Voyvodası Grigor Gika'nın icraatlarıyla ilgili Divan Efendisi'nin raporu için bkz. DAB, HAT., nr. 45679 A). İstanbul'a gönderilen resmi raporları yazar, fermanları okur ve tercüme eder, gerektiğinde İstanbul ve Tuna hattındaki Osmanlı istihdamları olan kaleler ile voyvodanın Türkçe yazışmalarını organize ederdi. Divan efendisinin görev ve yetkileri zamanla protokol ve Müslümanların anlaşmazlıklarını kadıyla birlikte karara bağlayacak şekilde genişlemiştir. Ayrıntılı değerlendirme için bkz. Petre Strihan, "Divan-Effendi în Ţara Românească şi Moldova în secolele XVII-XIX", Studii Revista de Istorie, XXI/5, Bucuresti 1968, s. 881-896.

${ }^{46}$ Hükümet merkezleri olan Bükreş ve Yaş'ta baş beşlü ağaları bulunurdu. Onların altında ise kazalarda beşlü ağaları ve en alt rütbede de beşlü neferlerinin yer aldığı anlaşılmaktadır. Beşlü ağalarının görev süreleri bir yıl ile sınırlıydı. Beşlü ağalarının esas sorumluluk alanı, askeri düzen ve intizamın sağlanmasından oluşmaktaydı (DAB, HAT., nr. 45361; HAT., nr. 45605; "fukarânın zabt u rabtı ve fukarâya bir gûne cevr ü ezâ olunmayarak himâyet ü sıyânetleri” şeklinde görevleri tanımlanmıştır bkz. HAT., nr. 41038).

47 Nikolay Golescu, delilbaşı ve tüfenkçibaşıların Arnavutlar yerine Müslümanlar arasında tayin edilmesiyle voyvodaların bir daha firar edemeyeceklerini öne sürmüştür (DAB, HAT., nr. 45522). 
beraber Eflak'ın muhafazasında istihdam edilmeleri, delilbaşı ve tüfenkcibaşıların Eflak gelirleri üzerinden tahsis edilecek ulufe ve tayinata kanaat etmeleri, bu askerlerin Eflak'ın idarî işlerine müdahil olmamaları ve eski dönemlerdeki gibi halktan geçerli bir sebepleri olmaksızın avaid ve diğer isimler altında herhangi bir şey talep etmemeleri, sayıları 2000 olarak belirlenen beşlü neferlerinin hizmetine lüzum kalmadığında sayılarının 1000'e düşürülerek sabitlenmesi.

5. Eflak'ta yeniden bir Rum isyanı çıktığı takdirde, sayıları 1000'e sabitlenecek olan beşlü neferleri yeterli gelmeyeceğinden sınırlarda bulunan Osmanlı vezirlerinin bölgeye beşlü neferi ve mühimmat sevk etmek için İstanbul'dan izin isteme mecburiyetinin kaldırılarak birliklerin süratle olay mahalline intikal ettirilmesi.

6. Eflak'a önceden getirilmiş olan Rum, Arnavut, Sırp milletleri, keşişleri ve tüm yabancılardan Rum İsyanı'na iştirak etmeyenlerin divan efendisi, baş beşlü ağası ve voyvodaların kefil olmaları kaydıyla Eflak'ta kalmaları ve Rumların hain emellerine hizmet edenlerin ise Rumeli'ye dağıtılmaları, ancak yabancıların Eflak'tan atılmalarını gerektiren bir suçları olmadığına dair voyvodalar tarafından kendilerine tezkireler verilse de bu türlü kimselerin boyar ve asker yapılmamaları veya hiçbir mercide görevlendirilememeleri için Osmanlı Devleti tarafından gerekli emirlerin çıkarılması, Rumeli tarafına gönderilecek kimseler arasında, isyana iştirak edenlerden veya bölgedeki düzeni bozabilme potansiyeline sahip olanların Osmanlı sınırlarındaki güvenlik önlemleri artırılarak Eflak tarafına geçmelerine izin verilmemesi.

7. Eskiden Eflak'ta sudit müessesesi bulunmadığından, suditlerin Eflak'taki emlaklarını yerli reayaya en kısa zamanda değeri üzerinden satışlarını yaparak Eflak'1 terk etmeleri, eğer Eflak'ta ikamet etmeyi sürdürmek isterlerse kendilerine patenta ${ }^{48}$ kağıtlarıyla tanınan ayrıcalıklardan vazgeçtiklerini resmi olarak bildirmeleri ve Eflak reayası gibi vergi ödemeye başlamaları şartıyla Eflak'ta kalmalarına izin verilmesi.

8. Eflak'a gelecek olan suditlere geçerli olan Eflak kanunları kapsamında muamele edileceğini kabul ettiğine dair bir kefil göstermesi ve suditin Rum, Arnavut ve diğer yasaklanmış yabancılardan olmadığını ispatlaması kaydıyla ticaret yapmasına izin verilmesi.

9. Eflak'ın tüm kurumlarında kendilerine itimat edilen Romenlerin istihdam edilmesi ve Rumlar başta olmak üzere diğer yabancilara görev verilmemesi.

10. Eflak reayasının huzur ve refahı için belirlenen ve fermanlarla güvence altına alınmış olan imtiyazların geçerli kılınması ve Eflak boyarlarının eskiden beri maiyetlerinde bulunan postelniklerin ibka edilmesi.

11. İsyana katılanlardan gerek firar edenlerin gerekse de katledilenlerin geride bıraktıkları emlak ve topraklar, Osmanlı Devleti tarafindan tayin edilecek memurlar marifetiyle, yerliler arasından taliplerine değeri üzerinden satılıp elde edilen gelirin tespiti ve hesabı yapıldıktan sonra ortaya çıkan karmaşadan zarar görmüş olan fakirlere ekonomik durumları değerlendirilerek taksim edilmesi.

\footnotetext{
${ }^{48}$ Konsoloslar, "patente" veya arşiv belglerinde geçen şekliyle "patenta" diye isimlendirilen bir çeşit kağıt (diploma, senet) ile istedikleri kişileri himayeleri altına alarak resmi ticaret muamelelerinde kendi vatandaşları gibi gösteriyorlardı. Patenta'nın Osmanlı Devleti ile bir ilgisi yoktu. Bu kağıdın verilmesi, yabancı temsilcinin doğrudan doğruya kendi yetkisindeydi. Bundan dolayıdır ki muafiyetin sağlanmasında Osmanlı Devleti'nin herhangi bir dahli olmadığından konsolosların kaç kişiye Patente kağıtları vererek muafiyet sağladıklarını belirleyebilmek oldukça güçtür. Patenta uygulaması hakkında bkz. Ali İhsan Bağış, Osmanlı Ticaretinde Gayri Müslimler (Kapitülasyonlar, Avrupa Tüccarları, Beratlı Tüccarlar, Hayriye Tüccarları 1750-1839), Ankara 1983, s. 30-31.
} 
12. Yabancı devletler tarafindan tayin edilen konsolosların ve tercümanların Rumlar yerine konsolos hangi ülkenin menfaatleri için Eflak'ta bulunuyorsa o ülkenin vatandaşı olan kimseler arasından seçilmesi.

13. Eflak'ta ilk zamanlarda yalnızca bir konsolos ve tercüman tayin eden yabancı devletlerin zamanla kazalara varana kadar konosolos vekili adı altında görevliler gönderip suditlerin sayısını kontrolsüz bir şekilde artırmaya sebep olduklarından dolayı tamamının kaldırılması, Eflak dahilinde ilk başlarda olduğu gibi yalnız bir konsolos ve tercümanın tayin edilmesi hususunun yabancı devletlerin elçilerine bildirilmesi.

14. Eflak ile sınır olan "serhâddât-ı hâkāniyyenin" eskiden beri geçerli olan nizam ve muamelelerinin aynı şekilde devam ettirilmesi.

15. Eskiden Osmanlı Devleti’nin talep ettiği kesimlik hayvanların teminini sağlayan Rum, Arnavut sayıcılar maiyetlerinde olan çobanlar eşkıya olduğundan bundan sonra talep edilen koyunların temini hususunda kasabbaşılarının güvendiği kimseyi sayıcı tayin edip göndermesi, beraberinde gelecek olan çobanlar ile hududa kadar gelip kasabbaşı tarafından alıkonulması ve kendisi Eflak hududuna geldiğinde topladığı koyunları Eflak çobanlarıyla Osmanlı tarafına gönderdiğinde serhadde bırakmış olduğu çobanlara teslim etmesi veya Eflak sınırında ahalisinden sayıcı tayin ederek İstanbul'a gönderilmesi hususunun kabul görmesi konusunda voyvoda ve boyarların görüş birliğinde olmaları.

16. Boyarların Eflak'ta yaptırmış oldukları kiliselerin gelirleri, Aynaroz başta olmak üzere bazı yerlerin kiliselerine tahsis edilmiş olduğundan belirlenen miktarın tahsili vesilesiyle Eflak'a gelen Rum keşişleri bir süredir tasallut edip bahsi geçen kiliseleri zapt etmişlerdi. Bu imkanlar dahilinde, çeşitli hıyanetlere cesaret ederek Fenerli voyvodaların yaptırmış oldukları Rum okullarında Eflak ahalisinin ayin ve mezheplerine aykırı şeyler öğrettikleri için bundan sonra Eflak kiliselerinde olan tüm Rum keşişlerin uzaklaştırılması, eskiden Rumlar arasından tayin olunan voyvodalar Eflak işlerine dair bazı şikâyet, istek ve önerilerini bildirmek için İstanbul'a gelecek boyarlara engel çıkardıklarından bundan sonra taleplerini iletmek üzere bir iki boyarın İstanbul'a gelmelerine voyvodalar tarafından engel olunmayarak izin verilmesi.

17. Kiliselerin sunduğu din hizmetlerinin yürütülmesi için İstanbul Rum Patrikhane'sinin keşiş göndermemesi, bunun yerine talep Bâbıâli'ye iletildiğinde Eflak'taki Kapı Kethüdası tarafından bu ihtiyacın giderilmesi, isyanı tamamıla ortadan kaldırmak için Rum mekteplerinin kapatılması ve bu mekteplerin gelirleri her neyse yukarıda yazılı firari ve maktullerin emlak ve arazilerinin kayıt altına alınması ve Osmanlı Devleti tarafindan tayin edilecek görevli marifetiyle deftere kaydedilerek miktarı ve sayısı belirlendikten sonra gereğinin yerine getirilmesi. ${ }^{49}$

18. İstanbul'a gelmesine izin verilen boyarlar, voyvodayı şikâyet ettiklerinde konunun etrafıyla araştırılması, eğer voyvoda suçlu bulunursa gerekli cezanın Osmanlı Devleti tarafından verilmesi, ihbar asılsız ise yine aynı şekilde şikâyetçi boyarın cezalandırılması.

19. Tayin edilecek voyvodaların İstanbul'daki işlerini takip etmek üzere iki kapı kethüdasının mutlaka yerli boyarlardan atanmasına izin verilmesi, voyvodanın bir oğlunun İstanbul'daki kapı kethüdalarına nezaret ederek Osmanlı Devleti'nin güvenini temin etmek için İstanbul'a getirilerek voyvoda azledilene kadar burada ikame edilmesi, oğlu olmayan

\footnotetext{
49 Nikolay Golescu bu maddeyle ilgili olarak okullarda eğitim gören Rum ve diğer yabancıların çocuklarının Aleksandr İpsilanti'ye tabi olduğunu kaydetmektedir. Okullarda bu çocukların halkın menfaatine uygun olacak tek bir kitap okutulmadığını öne sürmüştür. Bundan dolayı okullar kapatılmalı, Rum papazlar Eflak’tan çıkarılmalı ve Osmanlı Devleti tarafından tayin edilecek görevliler tarafından bu okullara el konulmasını istemiştir (DAB, HAT., nr. 45522).
} 
voyvodaların kızlarının, kızları yok ise erkek veya kız kardeşlerinin Osmanlı Devleti’nin güvenini temin etmek için İstanbul'a gönderilmeleri, voyvodalar azledildikten sonra çocukları ve aileleriyle birlikte İstanbul, Edirne, Filibe, Tatarpazarı ve Tekfurdağ 1 gibi yerlerden o zaman hangisinde kalmaları emredilirse orada ikamet etmeleri.

20. Eskiden beri ödenmekte olan avaid ve diğer hasılat dışında, Fenerliler tarafından kanunlara aykırı bir şekilde reayaya yüklenen ve zulüm haline gelen maddi külfetin tamamı kaldırılmak üzere ferman çıkarılmasını ve gerekli yaptırımların uygulanmasını Eflak boyarları talep etmişlerdir. ${ }^{50}$ Boğdan boyarları da Eflak'ta olduğu gibi Fenerli voyvodaların usulsüz uygulamalarından dolayı zulüm altında kaldıklarını Bâbıâli'ye bildirmişlerdir. Onlar da artık Boğdan yönetiminde Fenerli voyvodalar yerine eskiden olduğu gibi yerli boyarlardan bir voyvodayı görmek istemekteydiler. ${ }^{51}$

Nikolay Golescu, Eflak'a tayin edilen voyvodaların faaliyetlerinin sürekli denetlenmesini, Eflak reayasının hukuka aykırılık taşıyan uygulamalarla yüz yüze bırakılmamasını önermiştir. Bunun için her yıl voyvodayı denetlemek üzere Tuna kalelerinde bulunan paşaların mübaşirler tayin etmesini talep etmiştir. Eflak’tan padişahın istediği mal ve ürünlerin miktarının açık ve net bir şekilde belirtilmesini ve voyvodaların padişahların isteklerini tüm divan üyesi boyarlara okumak suretiyle hepsini haberdar etmesini, yolsuzlukların önüne geçilmesi için alınacak bir tedbir olarak sunmuştur. ${ }^{52}$ Boyarların önerileri alındıktan sonraki aşamada ise tekliflerin nasıl uygulamaya konulacağı hususu Babıali’nin gündeminde yer almıştır.

\section{Boyarların taleplerinin bâbıâli'de değerlendirilmesi ve düzenlemelerin uygulanmaya başlaması}

Boyarların talep ve önerileri İstanbul'daki muhataplarına iletildiğinde içlerinden voyvoda adayı olarak ön plana çıkan adaylardan iki tanesi (Grigor Gika ve Ioan Sandu Sturdza) Zahire Nazırı Ali Bey'in yanına getirilerek mülakat yapılması ve onun aracılığıyla Reisülküttab'ın ${ }^{53}$ Beylerbeyi'ndeki konağına ${ }^{54}$ götürülmesi planlanmıştır. Teklif ettikleri maddeler (yukarıda suralanan 20 madde), Osmanlı Devleti'ne uygun olacak şekilde incelenip tashih olunarak her bir madde ayrı ayrı müzakere edilmiştir. ${ }^{55}$ Ardından voyvoda adaylarına belirlenen bu maddeleri kabul ettiklerini ve aynı şekilde uygulayacaklarını belirten bir yazı kaleme aldırılmıştır. Yapılacak düzenlemelerin Rusya ile daha önce imzalanmış antlaşmalara aykırılık taşımaması Bâbıâli tarafından gözetilmiştir. ${ }^{56}$

Rum İsyanı devam ederken başkaldırıyı sonlandırmak için Osmanlı Devleti'nin aldığı tedbirler Rusya, Avusturya ve İngiltere'nin ilgilendiği bir konu haline gelmiştir. Rusya, Eflak ve Boğdan'a yerli boyarlar arasından yapılacak tayinlere ve isyanı bastırmak üzere alınan tedbirlere muhalefet etmeye başlamıştı. Osmanlı Devleti ise Rumlara itimadı kalmadığından yerli boyarlar arasından voyvoda tayini konusunda ısrarını sürdürmüş, ancak Rusya'nın

\footnotetext{
${ }^{50} \mathrm{DAB}, H A T .$, nr. 45528; HAT., nr. 45547; HAT., nr. 45547 A; HAT., nr. 45723 B; HAT., nr. 45766.

${ }^{51}$ DAB, HAT., nr. 45886 A; HAT., nr. 45591.

$52 \mathrm{DAB}, H A T .$, nr. 45522.

53 İncelediğimiz belgelerde Reisülküttab'ın ismi açıkça belirtilmemektedir. Ancak bu süreçte Reisülküttaplık makamında olan Hamid Bey 10 Kasım 1821 tarihinde görevinden azledilerek Sivas'a gönderilmiş ve yerine Sadık Efendi Reisülküttap tayin edilmişti. Bu görüşmelerin Hamid Bey ve halefi Sadık Efendi ile yapıldığg anlaşılmaktadır. Reisülküttaplık makamında yapılan değişikliğin detayı için bkz. Theophilus C. Prousis, Lord Strangford at the Sublime Porte (1821): The Eastern Crisis, I, İstanbul 2010, s. 257-259.

${ }^{54}$ Cevdet Paşa bu konağın ismini Yusuf Ziya Paşa yalısı olarak vermektedir bkz. Ahmed Cevdet Paşa, Tarih-i Cevdet, XII, İstanbul 1309, s. 45.

${ }^{55}$ DAB, HAT., nr. 45666; Mihail Guboğlu, "Eflak ve Boğdan Voyvodalarının Bab-1 Ali ile Münasebetleri", Belgelerle Türk Tarihi Dergisi, 1, Ankara 1967, s. 51.

${ }^{56}$ DAB, HAT., nr. 45723.
} 
baskısından dolayı Eflak ve Boğdan'ı güvenmediği Rum kaymakamların idaresinde bırakmıştı. Ayrıca Rusya ile mevcut antlaşmalara aykırı davranma niyeti taşınmadığı, mükâlemelerde özellikle vurgulanmışt1. ${ }^{57}$

Voyvoda adayları ile yapılan mülakatta önerilerinin büyük çoğunluğu aynı şekilde kabul edilirken, bazı konularda itirazlar olmuş ve yeniden değerlendirmeler yapılarak orta yol bulunmuştur. Eflak için 2000, Boğdan için 1000 beşlü neferinin giderleri Memleketeyn gelirlerinden karşılanması önerilmişse de bu durum Rusya'nın itirazlarına sebep olabileceği için voyvodaların kişisel gelirlerinden finanse edilmesi daha uygun bir seçenek olarak değerlendirilmiştir. Eskiden Beşlü neferlerinin giderleri, Eflak ve Boğdan gelirlerinden karşılanmaktaydı. Şimdi ise ancak olağanüstü bir durumda sayıları her iki memlekette kabul edilen miktarı ${ }^{58}$ geçerse o zaman fazlalık olan beşlü neferlerinin giderlerinin voyvodalar tarafından karşılanması teklif edilmiş ve bu konuda mutabık kalınmıştır. Voyvoda olacak şahsın azline kadar çocukları ve ailesi rehin olarak İstanbul'a getirilecek ve azledildiklerinde Osmanlı Devleti tarafından uygun görülen mahallerde ikamet ettirilecekti. Yapılan mülakatta voyoda adayları “rehin" tabirinin Eflak ve Boğdan'da yanlış anlaşılmalara sebep olacağını öne sürerek itiraz ettiler. Tüm aile fertlerinin yerine voyvodanın oğlunun kap1 kethüdası makamında istihdam edilmesine razı olduklarını bildirdiler. Kap1 kethüdası yapıldıkları takdirde, takip edecekleri işler vesilesiyle beyzadeler pek çok yere gidip gelmek durumunda kalacağından güvenliklerini sağlamak ve kendilerini korumak hayli güçleşecekti. Bundan dolayı Bâbıâli, yerli boyarlar arasından Eflak ve Boğdan için ikiş̧er kişiyi kapı kethüdası olarak atamayı, voyvoda oğullarının da kapı kethüdasına nezaret etmelerini ve rehin yerine emniyet gerekçesiyle İstanbul'da uygun bulunan mahalde ikametlerini daha doğru bulmuştur. ${ }^{59}$

Voyvodaların azledildiklerinde memleketlerinde ikamet edebilmeleri ve oğullarının boyarlık payesi alarak diğer boyarlar gibi kamu hizmetlerinde istihdam edilmesine dair boyarların izin istedikleri anlaşılmaktadır. Ancak mazul voyvodaların memleketlerine dönmelerine izin verilmemiştir. Bunun yerine, azledildikleri zamanın koşullarına uygun olacak şekilde İstanbul, Edirne, Sofya, Filibe, Tatarpazarı ve Tekfurdağı gibi yerlerden birinde ikamet edecekleri kendilerine bildirilmiştir. Oğullarının boyarlık payelerinin kaldırılması hususuna ise voyvodalar göreve gönderildikten sonra bakılacağı söylenmiştir. ${ }^{60}$

İstanbul'da Eflak ve Boğdan'a atanacak voyvodaların kim olacağ 1 hususunu görüşmek üzere yapılan toplantılarda yerliler arasından voyvoda tayini ehven-i şer" olarak değerlendirilmekteydi. ${ }^{61}$ Eflak ve Boğdan'da ortaya çıkan fesada sebebiyet verdikleri için Fenerli Rum voyvodaların artık güvenilmez oldukları aşikardı. Aynı zamanda Eflak ve Boğdan'ın yerli boyarlarından Bâbıâli'ye Fenerli voyvodaların ihaneti ve halka yaptıkları zulümleri bildiren şikâyetler ulaşmaktaydı. Yerli boyarlar, Fenerli voyvodalarla birlikte Rumlar başta olmak üzere tüm yabancı unsurların Eflak ve Boğdan'dan çıkarılmasını talep etmekteydiler. Osmanlı Devleti ise Fenerliler'den bezmiş görünen yerli boyarların bu talepleri geri çevrildiği takdirde Eflak ve Boğdan reayasının Rusya tarafına meyledebilme ihtimalini göz önünde bulundurarak isteklerinin kabul edilmesi yönünde irade göstermişti. ${ }^{62}$ Osmanlı Devleti'nin böyle bir yolu tercih etmesinde, daha önceden de vurgulandığg 1 şekilde yerli

\footnotetext{
${ }^{57} \mathrm{DAB}, H A T$., nr. 43077; HAT., nr. $44927 \mathrm{E}$

${ }^{58}$ (Eflak'ta 2000, Boğdan'da 1000)

${ }^{59} \mathrm{DAB}, H A T .$, nr. 45723.

${ }^{60} \mathrm{DAB}, H A T$., nr. 45723.

${ }^{61} \mathrm{DAB}, H A T .$, nr. 45591.

${ }^{62} \mathrm{DAB}, H A T$., nr. 45560.
} 
boyarların devlete kendilerini beğendirmek için en azından 5-10 sene sadakatle hizmet edecekleri yönündeki değerlendirmelerin de ciddi katkısı vardır. ${ }^{63}$

Rusya ve Avusturya taraflarına firar eden boyarlara emniyet olunmayacaksa da bunlar arasından devlete sadakat göstererek dönenler olduğu için bu bağl1lıklarına bir lütuf olarak ve Ioan Sturdza Boğdan'a ${ }^{64}$ Grigor Gika Eflak'a ${ }^{65}$ tayin edilmiştir. Voyvodalara hilat ve kuka giydirme merasimi esnasında, kendilerine pek çok Rum'un yakınları olduğu gerekçe gösterilerek Bükreş ve Yaş'a gitmeleri engellenmek istenmiştir. Ayrıca, tayin edilecek beşlü neferleri dolayısıyla yeniçerilerin istekte bulunmalarına firsat verilmemesi için yeni voyvodaların merasimlerinin Silistre'de yapılması uygun görülmüştür. Önce Silistre'ye ardından Bükreş ve Yaş'a yapılacak yolculuklarda, voyvodaların maiyetine mihmandar tayin edilmiş ve makamlarına oturana kadar onlara eşlik etmeleri kararlaştırılmıştır. ${ }^{66}$ Eflak voyvodasının yerli bir boyar olması, metropolid vekili ve bölgenin önde gelen seçkin kimseleri tarafından memnuniyet verici bir gelişme olarak algılanmış ve Osmanlı Devleti'ne teşekkür edilmiştir. $^{67}$

Meşveret meclisinde karar verildiği şekliyle voyvodaların oğulları İstanbul'a gönderilmek üzere ilk önce Silistre'ye getirilmișlerdir. ${ }^{68}$ Sturdza, voyvoda atandıktan sonra eskiden olduğu gibi büyük oğlu Nikola'yı ${ }^{69}$, Eflak Voyvodası Grigor Gika da oğlu Kostaki Gika'yı İstanbul'a göndermiştir. Ancak önceki dönemde olduğu gibi yerli voyvodaların çocukları artık Fener semtine değil, Rumlarla irtibat kuramayacakları Çengelköy'e yerleştirilmiştir. ${ }^{70}$ Boyarların Bâbıâli'ye ulaştırdıkları talepnamelerindeki 4. maddede kaydedildiği şekliyle, divan efendisi ve baş beşlü ağasının tayinleri, Osmanlı Devleti'nin iradesi doğrultusunda gerçekleşmiştir. Aynı zamanda Eflak'ta yeni bir isyan geliştiği takdirde, olayı süratle bastırmak için İstanbul'un onayı olmadan Eflak'a yeterli sayıdaki beşlü neferinin ulaştırılması ve serhaddeki muhafızlarla voyvodanın iş birliği yapabilmesi yönündeki önerileri kabul görmüştür. ${ }^{71}$

Voyvodaların tayini kararlaştırıldıktan sonra sıra bölgedeki nizamın yeniden kurulmasına gelmişti. Ioan Sandu Sturdza'ya hitaben yazılan bir hükümden öğrendiğimize göre, eskiden olduğu gibi tüfenkçibaşı ve delilbaşıların tayinlerinin Rum ve Arnavutlar arasından yapılması kaldırılmıştı. Bunun yerine İstanbul'daki mülakat esnasında boyarların önerdiği formüle uygun olarak tüfenkçibaşı ve delilbaşılar divan efendisi ile baş beşlü ağasının ortak görüşleri doğrultusunda belirlenecekti. Maiyyetlerine verilecek olan neferler ise voyvoda ve memleket

${ }^{63}$ DAB, HAT., nr. 45441; Süheyla Yenidünya Gürgen, Devletin Kahyası Sultanın Efendisi Mehmed Said Halet Efendi, İstanbul 2018, s. 317.

${ }^{64}$ Sturdza'ya Boğdan Voyvodalığı'nın tevcih edildiği tarih tahvil kayıtlarına yansıdğı kadarıyla 13 Temmuz 1822'ye tekabül etmektedir. DAB, Tahvil d., nr. 39, s. 229; DAB, A.DVN.DVE.d, nr. 80-4, s. 333-334; DAB, Cevdet Hariciye (C.HR.), nr. 45-2239.

${ }^{65}$ DAB, Tahvil d., nr. 39, s. 230. (14 Temmuz 1822).

${ }^{66} \mathrm{DAB}, A . D V N . D V E . d .$, nr. 82-6, s. 17; DAB, HAT., nr. 45723; Eskisi kadar görkemli ve şaşaalı olmamakla birlikte Gika ve Sturdza İstanbul'da Sadrazam, Reisülküttap ve Çavuşbaşı'nı ziyaret etmişlerdir. Sonrasında voyvoda tayin edildiklerinin bildiren beratlarını teslim almışlardır bkz. Theophilus C. Prousis, Lord Strangford at the Sublime Porte (1821): The Eastern Crisis, II, s. 187.

67 DAB, HAT., nr. 45530; II. Mahmud, "kendi cinslerinden olduğundan mesrûr olmuşlardır” şeklinde değerlendirmiştir. HAT., nr. 45610.

${ }^{68} \mathrm{DAB}, H A T$., nr. 45853.

${ }^{69} \mathrm{DAB}, H A T .$, nr. $45425 \mathrm{~A}$.

${ }^{70} \mathrm{DAB}, H A T$. , nr. 45425 B; Mihail Guboğlu'nun kaydettiğine göre Kostaki Gika, henüz 18 yaşında iyi derece Fransızca ve Almanca konuşabilen oldukça şık görünümlü ve nazik bir gençmiş. Geleceği oldukça parlak görülen bu genç beyzadenin hikayesi İstanbul'da gürültülü ve sansasyonel bir aşk macerası ile nihayete ermiş ve II. Mahmud'un emriyle görevinden alınarak sınır dışı edilmiştir. Bu ilginç hikayenin arşiv kaynaklarına dayalı detayları için bkz. Mihail Guboğlu, "Eflak ve Boğdan Voyvodalarının Bab-1 Ali ile Münasebetleri”, s. 61-67.

${ }^{71}$ DAB, HAT., nr. 45546. 
boyarlarının ortak iradeleri doğrultusunda yerli ve gönüllü reaya arasından seçilecekti. Beşlü neferlerinin ulufeleri eski usul doğrultusunda memleket gelirlerinden karşılanacak, eğer olağanüstü ihtiyaç olursa voyvodanın kendi memlahası başta olmak üzere sağladığı kişisel gelirlerden bunların finansmanı yapılacaktı. Beşlü neferleri, yerlilerden tayin edilecek zabitler ve güvenlik görevlileri ile birlikte Boğdan'ın muhafazasını sağlayacaklardı. Boğdan'da güvenlik sağlandıktan sonra sayıları 500'e indirilecek ve ulufeleri eski usul doğrultusunda ödenecekti. Eğer olağanüstü bir durum vukubulursa İstanbul' da boyarların teklif ettiği şekilde beşlü neferlerinin lojistik ihtiyaçları en hızlı biçimde İstanbul'dan emir beklemeye gerek kalmaksızın tedarik edilecekti. Rum, Sırp, Bulgar, Arnavut ve diğer yabancı unsurlara güvenilmediğinden Rumeli'de uygun görülen mahallere nakilleri gerçekleştirilecekti. Boğdan'daki yabancıların isyana iştirak etmedikleri ve bozguncular arasında yer almadıkları konusunda yerli boyarlar kefil olurlarsa Boğdan'da kalmalarına izin verilecekti. Ancak Boğdan'da kalsalar bile kendilerine herhangi bir idari görev veya makam tahsisi yapılamayacaktı. Sınır geçişlerindeki denetimler sıkılaştırılacak ve bu işin yürütülmesinde kapı kethüdasiyla $\operatorname{spatar}^{72}$ koordinasyon içerisinde olacaktı. ${ }^{73}$

Boğdan'daki suditler, mal varlıklarını Romenlere satarak memleketi terk edeceklerdi. Boğdan'ın iç idaresinde istihdam edilecek kimseler yerliler arasından "ehl-i trz ve mücerebbü'l-etvâr ve mû 'temed” olanlardan seçilecek, Rumlar ve diğer yabanc1 unsurlar tercih edilmeyecekti. Eskiden adet olduğu üzere, boyarların hizmetinde postelnikler yeniden istihdam edilecekti. Fakat bu yapılırken reayanın zarar görmemesine ve haksızlığa uğramamasına özen gösterilecekti. Boğdan'la hemhudut olan Osmanlı sınırlarının eskiden beri geçerli olan nizamları ve muameleleri aynı şekilde uygulanmaya devam edecekti. Rum voyvodalar zamanında muhalif boyarların İstanbul'a şikâyetlerini bildirmeleri engellenmiş olduğundan bundan sonra bir iki tanesinin mahzarlarıyla birlikte İstanbul'a gelmeleri engellenmeyecekti. Bâbıâli'ye arz ettikleri şikâyetler, Osmanlı Devleti tarafından araştırılarak haksız olan tarafa (asılsız ihbarda bulunan şikâyetçiye veya voyvodaya) gerekli yaptırımlar uygulanacaktı. Rum keşişlerin görevden uzaklaştırılması ve din işlerinin yürütülmesi için yapılacak atamalarla ilgili boyarların İstanbul'da sundukları talepleri aynı şekilde uygulamaya konulacaktı. Voyvodaların gelirleri için eskiden beri kanun haline gelmiş miktarlar dişında Fenerli voyvodalar tarafından reayaya fazladan yüklenen vergilerin ve mali uygulamaların tamamı yürürlükten kaldırılarak bir daha talep edilmesi yasaklanmıştır. ${ }^{74}$

İsyana iştirak edip daha sonra firar veya katledilenlerin emlak ve arazilerinin zabtı için tayin edilecek mübaşirler, voyvodalar Bükreş ve Yaş'a ulaştıktan sonra görevlendirilecekti. Divan efendileri "ketebe-i aklâmdan" dürüst ve tavırları bilinen, itimad edilen katipler arasından seçilecekti. Baş beşlü ağalarının seçimi ise Rumeli'den kendisine güvenilen ve asker istihdamı konusunda yetenekli ayan ve ağalardan olacaktı. Beşlü ağalarının görevleri bir yıl süreyle sınırlandırılacaktı. Azledildiklerinde memleketlerine döneceklerdi. $\mathrm{Bu}$ şartlar doğrultusunda, Eflak Baş Beşlü Ağalığı'na Pazarcık Ayanı Kavanos-zâde Kapıcıbaşı Hasan Bey tayin olunmuştu. Kendisinin hazırlanması ve voyvodanın talebi doğrultusunda maiyetine 2000 kişiden oluşan aylıklı beşlü neferini toplamasının ardından Silistre Valisi'nin yanına gidecek ve valinin emriyle Eflak tarafına geçecekti. Boğdan beşlü ağalığına da henüz münasip bir aday tespit edilmediğinden, bu konudaki çalışmalar aynı Eflak'ta uygulanan usul doğrultusunda takip edilecekti. ${ }^{75}$ Eflak ve Boğdan boyarlarının taleplerinin değerlendirildiği

\footnotetext{
${ }^{72}$ Spatar, Eflak ordusunun kumandanlı̆̆ını yapan yüksek rütbeli askerdir.

${ }^{73} \mathrm{DAB}, A . D V N . D V E . d, \mathrm{nr} .80-4$, s. 333.

${ }^{74}$ DAB, A.DVN.DVE.d, nr. 80-4, s. 334.

75 Boğdan Baş Beşlü Ağalığı'na 23 Ağustos 1822 tarihinde Silahşoran-1 Hassa'dan Babadağ Ayanı Eyüb Ağa getirilmiş (DAB, HAT., nr. 45792) ve maiyetindeki 1000 beşlü neferi ile Silistre'den Yaş'a gitmek için yola
} 
meşveret meclisinde kapı kethüdalarının durumu da görüşülmüştür. Buna göre, Fenerli voyvodalar döneminde tayin edilen kapı kethüdaları, pek çok asılsız söylentinin kaynağı olarak görüldüğünden yerli boyarlar arasından atanacak kapı kethüdalarının bundan sonra İstanbul'da "irz ve edepleriyle" oturmaları ve görevlerinin gereği olarak Bâbıâli, Bab-1 Defetri ve Darbhane-i Amire gibi kurumlara Memleketeyn işleri için izinsiz gidip gelmemeleleri tembih edilmiştir. $^{76}$

Eflak ve Boğdan'da beşlü ağaları görev mahalline ulaştıklarında bölgenin muhafazası için bulunan askerler Silistre Valisi'nin emri doğrultusunda geri çekileceklerdi. Eflak ve Boğdan'daki beşer bin neferden oluşan Osmanlı askerlerinin ulufeleri, memleketeyn hasılatından karşılanacaktı. Eflak'ta birikmiş ulufelerin tamamı ödense de Boğdan'in bu meblağı karşılamaya maddi kudreti bulunmadığından ileride bir şekilde çaresine bakılacaktı. Divan efendilerine gizli yazışmalarda kullanılmak üzere şifre anahtarı verilmesi, kendilerine aktarılacak olan gizli talimatların bildirilmesi istenmişti. Baş beşlü ağalarıyla birlikte divan efendileri, voyvodaların hal ve hareketlerine her daim vakıf olmak ve önemli gelişmeleri aktarmakla sorumlu tutulmuşlardı. Voyvodalar firar etme teşebbüsünde bulunurlarsa bunu engellemekle yükümlüydüler. Başkaları, eğer Memleketeyn'de kargaşa çıkarmaya çalışırsa durumu Silistre valisine bildirmek, beşlü ağalarına verilen gizli talimatta yer almaktaydı. ${ }^{77}$

Yerli voyvodalar tayin edilince onların hâkimiyetini gölgeleyebilecek tüm isimlerin farklı yerlere gönderilmesi, meşveret meclisinde kararlaştırılmıştır. II. Mahmud'un ikazi ${ }^{78}$ doğrultusunda Bükreş, Yaş ve Kroyova'daki kaymakamların firarlarını önleyecek tedbirler alınmıştır. ${ }^{79}$ Bu kapsamda Eflak Kaymakamı Negri, Kara Eflak Kaymamakamı Samurkaşoğlu ve Boğdan Kaymakamı Stefan'ın firar edebilecekleri öngörüldüğünden artık Eflak ve Boğdan'da bulunmaları tehlikeli bir hal almıştı. Bu sebeple henüz İstanbul'da bulunan yeni voyvodalara durum bildirilerek ya maiyetlerindeki boyarlardan ya da Memleketeyn'de uygun gördükleri boyarlardan üç kişinin kaymakam olarak atanması ve buna göre fermanlarının gizlice çıkarılması istenmiştir. Yeni Eflak ve Boğdan kaymakamı Silistre'ye, Kara Eflak Kaymakamı da Vidin'e ulaştığında, eski kaymakamlardan Negri ve Stefan'ın Silistre'de, Samurkaşoğlu'nun da Vidin'de tutuklanmasının ardından üç yeni kaymakamın valilerin nezaretinde görev mahallerine ulaştırılması tavsiye edilmiştir. ${ }^{80}$ Eski kaymakamların ise etrafları ile haberleşemeyecekleri ve denizden uzak yerlere gönderilmelerine özen gösterilmiştir. Silistre'de olan eski Eflak Kaymakamı Konstantin Negri, Şereflikoçhisar'a ve Boğdan Kaymakamı Stefanki de Göynük'e gönderilmiştir. ${ }^{81}$ Arşiv kayıtlarından tespit edebildiğimiz kadarıyla Eflak Kaymakamı Konstantin'in kardeşinin isyancılarla irtibatı vardı. Bundan dolayı Şereflikoçhisar'dan İstanbul'a çağrılarak Fener semtinde idam edilmesi II. Mahmud tarafından emredilmiştir. ${ }^{82}$

Eflak Voyvodası Grigor Gika, 26 Eylül 1822 tarihinde Bükreş'e varmış ve Eflak'ın yönetimini devralarak çalışmalarına başlamıştır. ${ }^{83}$ Yaş’a ulaşan Boğdan Voyvodası Ioan Sandu

çıkmıştır (HAT., nr. 45449); Boğdan Divan Efendiliği'ne de Ion Sandu Sturdza'nın Voyvoda tayin edilmesiyle birlikte Hacegan-1 Divan-1 Hümayun'dan İbrahim Nabi Efendi atanmıştır (DAB, A.DVN.DVE.d, nr. 80-4, s. 334).

76 DAB, HAT., nr. 45723; Hasan Bey'in Baş Beşlü Ağalığı'na tayinini bildiren hüküm için bkz. DAB, A.DVN.DVE.d., nr. 82-6, s. 20-21.

${ }^{77} \mathrm{DAB}, H A T .$, nr. 45723.

${ }^{78} \mathrm{DAB}, H A T .$, nr. 45591.

${ }^{79}$ DAB, HAT., nr. 45961; Bilhassa Bükreş Kaymakamı Negri’nin kardeşi Rusya'nın muteber generallerindendi ve karısı da İpsilanti'nin kızıydı. Firar edebileceğine dair haberler Bâbıâli'ye ulaşmaktaydı (HAT., nr. 45591).

${ }^{80} \mathrm{DAB}, H A T$., nr. 45723.

${ }^{81}$ DAB, HAT., nr. 45449 A.

${ }^{82} \mathrm{DAB}, H A T .$, nr. 16805; Boynuna asılan yafta için bkz. HAT., nr. 16805 A.

${ }^{83} \mathrm{DAB}, H A T$., nr. 45879. 
Sturdza da 21 Ekim 1822 tarihinde divanı toplayarak voyvodalık beratını okutmuş ve memleketin önde gelenlerine voyvoda olarak görevlendirildiğini ilan eden prosedürü gerçekleştirdikten sonra çalışmalarına başlamıştır. ${ }^{84}$

Eflak Voyvadası Grigor Gika, görevine başladıktan sonra Baş Beşlü Ağası Hasan Bey’de Rumeli'den seçilen beşlü neferleri ile Bükreş'e ulaştı. ${ }^{85}$ Voyvoda Gika ile müştereken yürüttükleri çalışmalar kapsamında bölgede isyana iştirak edenlerin tespiti ve cezalandırılmasıyla meşgul olmuşlardır. ${ }^{86}$ Grigor Gika'nın önemli icraatlarından biri de çocuklarına boyarlık rütbesi ve imtiyazları verebilmek ve bunu sürekli geçerli kılmak için izin istemesi olmuştur. ${ }^{87}$ Boğdan'a tayin edilen Ioan Sturdza'nın soylu biri olmaması nedeniyle Boğdan boyarları arasında ayrılıklar ortaya çıkmış ve voyvodaya bağlılıkları zayıflamıştı. Voyvoda'ya yeniden itaat ettirilmeleri için Ioan Sturtza, İstanbul'dan bu anlamda bir nasihat hüviyeti taşıyan buyruldu gönderilmesini istedi. ${ }^{88} \mathrm{Bu}$ kapsamda voyvodanın talebi doğrultusunda boyarlara Osmanlı Devleti tarafindan sadık ve muteber bir idareci olarak kabul edilen voyvodalarıyla uyumlu bir şekilde çalışmaları, halkı içerisinde bulunduğu zor durumdan daha müreffeh bir yaşama kavuşturmaları, mükellef oldukları vergileri eksiksiz iletmek ve bölgedeki beşlü neferlerinin ihtiyaçlarını karşılamak için bunu yapmaları tavsiye olunmuştur. ${ }^{89}$

Voyvodalar görevlerine başladıklarında Memleketeyn'in birikmiş borçlarının ödenmesi ve bozulan ekonomik koşulların iyileştirilmesi için kapsamlı çalışmalar yapmışlardır. Eflak'ta isyanla birlikte bozulan müesses nizam, 8000 kese akçe tutarında bir borç yükü ortaya çıkarmıştı. Bu konuda emsal oluşturmak adına eskiden reayanın zor durumda kalmasından dolayı vergi borçlarında muafiyet tanınıp tanınmadığı Divan-1 Hümayun kayıtlarından araştırılmıştır. Kayıtlar doğrultusunda Temmuz $1803^{\prime}$ te $^{90}$ Eflak'ın 2000 kese akçe borcunun biriktiği tespit edilmiştir. O dönemde ahali, bu borcu ödeyebilecek maddi güce sahip olmadığından vergi muafiyeti tanınan metropolit, psikoposlar, boyarlar ve diğer kimselerle manastırlardan 1803 yılına mahsus olmak üzere 900 kese akçe tutarındaki bal ve şarap vergileri tahsil edilerek söz konusu borcun ödenmesi sağlanmıştır. Ancak isyan başladıktan sonraki iki yıl içerisinde 1803 tarihinde birikmiş borcun dört katı tutarındaki bu meblağın kimler tarafından hangi gider kalemlerine aktarıldığ tam olarak tespit edilmeden herhangi bir af getirilemeyeceği ve kolaylık sağlanamayacağ 1 Eflak kapı kethüdasına bildirilmiştir. ${ }^{91} \mathrm{Bu}$ doğrultuda vestiyar kayıtları çıkarılarak Eflak voyvodası tarafından İstanbul'a bildirilmiş ${ }^{92}$ ve harcama kalemleri tek tek sıralanmıştır. ${ }^{93}$ Bulunan ara çözüme göre 4.000 .000 kuruş civarındaki borcun 500.000 kuruşu boyarlardan ve geri kalanlar da dini müesseselerin vakıflarından elde edilecek iki yıllık gelirin ipotek edilmesi suretiyle ödenmesi teklif

\footnotetext{
${ }^{84} \mathrm{DAB}$, HAT., nr. 1561-24.

${ }^{85}$ Hasan Bey Bükreş'e geldiğinde yeniçerilerin bölgedeki görevi tamamlandığından çekilmişlerdi. Kavanos-zâde Hasan Bey'in maiyetindeki toplam 2000 beşlü neferi Eflak kazalarına dağılmış ve kendisinin maiyetindeki 200 kadar beşlü neferiyle birlikte Bükreş’teki görevine başlamıştı. Theophilus C. Prousis, Lord Strangford at the Sublime Porte (1821): The Eastern Crisis, II, s. 297.

${ }^{86} \mathrm{DAB}, H A T$., nr. 39910.

${ }^{87} \mathrm{DAB}, H A T$., nr. 34867.

${ }^{88} \mathrm{DAB}, H A T .$, nr. 45510

${ }^{89} \mathrm{DAB}$, HAT., nr. $45510 \mathrm{D} ;$ HAT., nr. 45510C

${ }^{90}$ Konstanin İpsilanti'ye verilen fermanın sureti için bkz. DAB, HAT., nr. $45454 \mathrm{H}$.

${ }^{91}$ Vergilerde kolaylık sağlanmasına dair Bâbıâli’ye iletilen bu talebe verilen cevabı II. Mahmud beğenmiştir. Eflak tarafından gelecek cevap doğrultusunda yine kayıtlara bakılarak gerekli adımın atılmasını tavsiye etmiştir (DAB, HAT., nr. 45454).

${ }_{92} \mathrm{DAB}, H A T$., nr. $45454 \mathrm{C}$.

${ }^{93} \mathrm{Bu}$ borcu oluşturan masraf kalemlerinin ayrıntılı dökümü için bkz. DAB, HAT., nr. $45454 \mathrm{E}$.
} 
edilmiştir. ${ }^{94} 1803$ 'teki ödeme planının emsal alınarak hareket edilmesini II. Mahmud uygun görmüştür. ${ }^{95}$ Boğdan'da, isyan akabinde lüzum duyulan vergilerin tahsili aşamasında, haksız vergi koyduğu yönünde Voyvoda Sturdza şikâyetlere konu olmuştur. Ancak esasında Sturdza'nın toplamaya çalıştığı meblağ, bir yıl önceki hesap açıklarının kapatılması ve Boğdan'daki 1000 beşlü neferinin ihtiyaçlarının karşılanmasını sağlamaya yönelikti. ${ }^{96}$

Eflak ve Boğdan'a 1822 yılında yerli voyvodalar gönderildikten sonra 1822-1826 yılları arasında her iki memleketten Osmanlı Devleti'ne çeşitli adlar altında ödenen vergileri Darbhane-i Amire kayıtlarından öğrenebilmekteyiz. Darbhane-i Amire gelirleri arasına kaydedilen bu vergi kalemleri ve miktarları aşağıdaki tabloya (Tablo I) aktarılmıştır. Belirtilen tarihler arasında Eflak ve Boğdan voyvodaları hisselerine düşen rikabiyye ${ }^{97}$ ve 1ydiyyeleri $^{98}$ eksiksiz ödemişken taahhüdiye ${ }^{99}$ adı altında göndermeleri gereken miktarı İstanbul'a ulaştıramamışlar ve bu konuda çözüm arayışı içerisine girilmiştir. Eflak ve Boğdan kapı kethüdalarıyla İstanbul'da ikamet eden oğulları Darbhane-i Amire'ye çağrılarak taahhüdiye adı altında mükellef tutuldukları miktarı ödemeleri istenmiştir. Boğdan voyvodası bu anlamda borcunu ödemeyi taahhüt ederken, Eflak voyvodası ise ahalinin perişan vaziyetini öne sürerek taahhüdiye vergisinin affını istemişse de Darbhane-i Amire yönetimi bu konuda taviz vermeme eğiliminde olmuştur. Ancak Eflak voyvodasının 1srarlı talepleri karşısında taahhüdiye kapsamında biriken dört yıllık vergiden üç yıl için hesaplanan 18 yük, 150.000 kuruş bir defaya mahsus olmak üzere silinmiş ve 6 yük, 50.000 kuruşun ödenmesi kararlaştırılmıştır. 1826 yılı itibarıyla ise Eflak'tan gönderilen taahhüdiye de dahil hissesine düşen miktarın tamamını ödemesi konusunda mutabık kalınmıştır. ${ }^{100}$

\begin{tabular}{|l|c|c|}
\hline Vergi Kalemi & Eflak’tan Tahsil Edilen Vergi Miktarı & Boğdan'dan Tahsil Edilen Vergi Miktarı \\
\hline Rikabiyye & 40.000 kuruş & 25.000 kuruş \\
\hline Iydiyye & 90.000 kuruş & 90.000 kuruş \\
\hline Taahhüdiyye & 6 yük 50.000 kuruş & 3 yük 15.000 kuruş \\
\hline
\end{tabular}

Tablo I: Eflak ve Boğdan'dan 1822-1826 Yıllarında Tahsil Edilen Vergiler ${ }^{101}$

Grigor Gika'nın uyguladığı vergi rejimi, ahaliye ağır geldiği gerekçesiyle memnuniyetsizliğe sebep olmuştur. Küçükbaş hayvan vergileri ve kazalardan alınan vergilere memleketin giderlerini gerekçe göstererek kanunlarla bağdaşmayacak şekilde 8 kuruş zam yapıp tahsil etmişti. Voyvoda, aynı zamanda komislik görevini isyandan sonra belirlenen

${ }^{94} \mathrm{DAB}, H A T .$, nr. 45454 D; HAT., nr. 45454 G; HAT., nr 45454 F. İki yılda üç taksit halinde borcun ödenmesi planlanmıştır. HAT., nr. 45780.

${ }_{95} \mathrm{DAB}, H A T$., nr. $45454 \mathrm{H}$.

${ }^{96} \mathrm{DAB}$, HAT., nr. $45510 \mathrm{~A}$.

${ }^{97}$ Rikabiyye, sadrazam ve bazı devlet adamları tarafindan belirli zamanlarda padişaha verilen verilen hediyeleri ifade etmek üzere kullanılan bir tabirdir. Aynı zamanda rikabiyye, önde gelen saray mensuplarının tayinleri münasebetiyle takdim edilen peşkeşlere de bu ad verilirdi (Mehmet Zeki Pakalın, "Rikâbiyye", Osmanlı Tarih Terimleri ve Deyimleri Sözlüğü, III, İstanbul 1993, s. 46). Belgelerden anlaşıldığı kadarıyla, Eflak ve Boğdan voyvodalarının bu ad altında vergi ödedikleri görülmektedir.

98 Iydiyye, bayramlar münasebetiyle devlet adamları arasında alınıp verilen hediyeleri ifade etmektedir bkz. Fehmi Y1lmaz, Osmanlı Tarih Sözlüğ̈̈, İstanbul 2010, s. 262.

99 Taahhüdiyye, önceden belirlenmiş vergilere ilave olarak halktan para talep edilmesidir (Abdülkadir Özcan, “İane”, DİA, XIX, İstanbul 1999, s. 229). İlgili maddede verilen bilgi, referans kaynağımız olan belgedeki bilgilerle örtüşmektedir.

${ }^{100}$ DAB, DRB.d., nr. 131.

${ }^{101}$ DAB, DRB.d., nr. 131. 
şartlara aykırı olarak bir Rum'a vermiştir. Borç listelerinin yanlış düzenlendiği şeklinde bazı boyarların itirazları olsa da hesaplarda herhangi bir uyumsuzluk olmadığı konusunda kendileri tehdit edilip korkutularak imzalar attırılmış ve söz konusu hesap dökümleri İstanbul'a ulaştırılmıştır. Tüfenkci ve delilbaşılara voyvoda, divan efendisi ve baş beşlü ağasının mutabakatı ve kefaleti sağlanmadan silah verildiği, bu neferlerin bazılarının isyana iștirak eden kimselerden olduğu Bâbiâli'ye bildirilmiştir. Ayrıca kır serdarı ${ }^{102}$ adıyla istihdam edilen neferlerin de Eflak'taki silahlı birlikleri oluşturduğu, divan efendisinin raporunda kaydedilmiştir. ${ }^{103} 9$ Mart 1823 tarihli bir arşiv kaydından anlaşıldığına göre, yerli reayadan usule aykırı bir şekilde tayin edilen neferler kaldırılmış ve halka dağıtılan silahlar toplanmıştır. ${ }^{104}$

Boğdan'da olduğu gibi Eflak’ta da voyvodanın halka zulmettiğinden şikâyetci olan boyarlar durumu Bâbıâli'ye bildirmişlerdir. Yapılan araştırmada ihbarın asılsız olduğu anlaşılmıştır. Eflak boyarlarının yerli voyvoda tayin edilmesi için İstanbul'a ulaştırdıkları taleplerde voyvoda hakkında asılsız ihbarlarda bulunanların cezalandırılması istendiğine değinilmişti. Ancak çeşitli dedikodulara sebebiyet verilmek istenmemesi ve Rusya ile yeni bir uzlaşmazlık alanının ortaya çıkmaması için gerçek dışı beyanlarda bulunan boyarların bir defaya mahsus cezalandırılmamaları ve moşyelerine geri gönderilmeleri istenmiştir. ${ }^{105}$ Yerli voyvodaların yönetimlerinde yaşanan bu türlü aksaklık ve şikâyetler karşısında "Vâkı' $a$ şu voyvoda olan gâvurlardan Devlet-i Aliyye'mize hüsn-i hidmet ve sadâkat me'mûl değil ise de..." ifadeleriyle II. Mahmud memnuniyetsizliğini dile getirmiş ve Rus elçisinin yeni isteklerde bulunmasının önüne geçilmesi için konunun geçiştirilmesini istemiştir. ${ }^{106}$

Eflak ve Boğdan'da Rum voyvodalar ve bu voyvodalara bağlı olan boyarlar tarafindan yerleştirilen Rum, Sırp, Bulgar ve Arnavutlar ve keşişler yerli boyarlar üzerinde tahakküm kurarak onlara zulmettiklerinden, bir daha Eflak'a ayak basmamaları Bâbıâli tarafından kabul edilmiş ve uygulamaya konulmuştur. ${ }^{107}$ Eflak ve Boğdan'daki tüm yerleşik yabancı unsurların çıkarılmasını hedefleyen bu düzenlemenin gerekçeleri arasında, bölgede asayiş ve güvenliği tam anlamıyla tesis etme düşüncesi de vardı. Babadağı Muhafızı'nın 30 Kasım 1822 tarihli yazısından anlaşıldığına göre, İstanbul'daki mülakatta kararlaştırıldığı şekliyle Osmanlı sınırlarına gelen kişiler, kapsamlı bir şekilde soruşturulduktan sonra geçişlere izin verilmekteydi. ${ }^{108}$ İsyana Eflak'taki din adamlarının da iştirakinden dolayı bölgede kadim düzen yeniden tesis edildiğinde metropolitlerin atamaları Bâbıâli'ye sorulmuştur. İstanbul'da yapılan araştırma ve değerlendirmelerin ardından uygun görülen kimsenin metropolit olarak atanabildiği arşiv kayıtlarından anlaşılmaktadır. ${ }^{109}$

Devlete karşı ihanetleri açık olan bir kısım Rumla birlikte Memleketeyn'e Rumlar eliyle yerleştirilmiş Arnavut, Bulgar, Sırp vs. yabancıların kovulması işine II. Mahmud'un daha

\footnotetext{
${ }^{102}$ Kır Serdarı, Osmanlı taşra idari birimlerinde, zabıtanın görev ve yetki alanının dışında kalan yerlerde kolluk görevi yürütenlere verilen isimdir. Kır Serdarlığı ile ilgili ayrıntılı bilgi için bkz. Neslihan Ermahiş, Osmanlı Imparatorluğu’nda Bir Kolluk Kuvvet: Kır Serdarlı̆̆ı, Cumhuriyet Üniversitesi Sosyal Bilimler Enstitüsü, (Basılmamı̧̧) Yüksek Lisans Tezi, Sivas 2018.

${ }^{103} \mathrm{DAB}, H A T .$, nr. 45679 A.

${ }^{104}$ DAB, HAT., nr. 38777 A; Söz konusu neferlerin voyvodanın maiyyetinde, Kurta dedikleri sarayda ve hududlarda istahdam edildiklerini bildiren Boğdan voyvodasının yazısı için bkz. DAB, HAT., nr. 37877 D.

${ }^{105} \mathrm{DAB}, H A T .$, nr. 45587.

${ }^{106} \mathrm{DAB}, H A T .$, nr. 45695.

${ }^{107}$ DAB, A.DVN.DVE.d, nr. 80-4, s. 334

${ }^{108}$ DAB, Cevdet Dahiliye (C.DH.), nr. 206-10272; Aynı uygulama İbrail ve Maçin'de de yapılmaktaydı. DAB, C.HR. nr. 66-3283; C.HR. nr. 84-4195; geçişlerdeki denetimi konu edinen bir talimatname sureti için bkz. DAB, HAT., nr. $45674 \mathrm{~B}$.

${ }^{109} \mathrm{DAB}, H A T .$, nr. $45454 \mathrm{~B}$.
} 
sonra bakılması tavsiyesi doğrultusunda bu konu voyvodaların tayinlerinden sonraya bırakılmıştır. ${ }^{110}$ Uygun vakit geldiğinde Eflak ve Boğdan'da Fenerli Rum boyarların yerine yerlileri ikame etmek için çalışmalar başlatılmıştır. Ancak bu çalışmalar neticesinde boyar sayıları gereğinden fazla artırıldığı için tanınan vergi muafiyetlerinden dolayı uzun vadede fakir reayanın üzerine binen mali külfeti arttıracağı yönündeki endişeler, ciddi bir şekilde dile getirilmiştir. Divan Efendisi Nabi Efendi'nin bu husustaki raporu, boyarların sayısının ölçüsüz bir şekilde artırdırdığını ortaya koyması bakımından önemlidir. ${ }^{111}$ Boğdan Voyvadası'nın boyarlardan para toplaması da boyarlar ile voyvoda arasındaki sürtüşmenin bir diğer önemli nedeni olarak göze çarpmaktadır. ${ }^{112}$ II. Mahmud ise Rusya başta olmak üzere Avrupa devletlerinin bölgede istihdam edilen beşlü neferlerinden rahatsılık duyduklarını ancak onların beşlü neferlerinin kaldırılması yönündeki talepleri geçiştirildiği için voyvoda ile boyarlar arasındaki sürtüşmeleri bahane ederek bölgenin işleyişine müdahil olmak istediklerini düşünmektedir. Bundan dolayı rahatsızlık unsuru olarak beliren boyarların cezalandırılmasını ve karmaşanın en hızlı biçimde sonlandırılmasını istemiştir. ${ }^{113}$ Nihayetinde, Ağustos 1823 'te İstanbul'a ulaşan haberlere göre, Rum İsyanı sonrasında Eflak boyarlarının taleplerine uygun olarak Eflak’taki kurumlarda görevli olan Rum, Bulgar ve Arnavut memurlar azledilmiştir. ${ }^{114}$

Yerli voyvodaların talepleri doğrultusunda Bükreş ve Yaş dışındaki konsolos vekillerinin görevlerinin sonlandırılması için çalışmalar başlamıştır. Konsolos ve konsolos vekilleriyle ilgili düzenlemeler yapılırken Osmanlı Devleti, Rusya ile önceden imzaladığı 1774 Küçük Kaynarca ve 1792 Yaş Antlaşması hükümlerini referans almıştı. Söz konusu iki antlaşmanın şartları uyarınca, Osmanlı sınırları dahiline tayin edilen konsoloslar ve konsolos vekilleri Rus kökenli olmalıydı. Osmanlı tebaasının ${ }^{115}$ konsolos veya konsolos vekili olarak görevlendirilmesi, her iki antlaşmanın ihlali anlamına gelmekteydi. Bundan dolayı artık Osmanlı tebaası olan Rumlardan konsolos tayin edilmesi, Osmanlı Devleti ve Rusya arasında geçerli olan antlaşmalar uyarınca yasaklanmış, ${ }^{116}$ sonraki düzenlemelerde de konsolos vekillikleri kaldırılmıştır. Bükreş ve Yaş dışındaki konsolos vekillerinin görevlerinin sonlandırılması ise İngiltere, Fransa, Avusturya ve Prusya'nın itirazlarına konu olmuştur. Bu devletlerin elçilerinin yaptığı değerlendirmelere göre başkentler dışındaki yerleşim alanlarına konsolosluk vekaletinin veya acentelerin faaliyetlerinin kısitlanması ticaretin aksamasina neden olacağı gibi aynı zamanda geçerli olan kapitülasyonların da ihlali anlamına geliyordu. ${ }^{117}$ Avusturya'nın Osmanlı belgelerine yansımayan çıkar ilişkileri zarar görmeye başlamıştı. İtirazların temelinde bu gerçek vardı. 1812'den sonra Eflak ve Boğdan'daki, özellikle başkentlerdeki boyarlar Avusturya'lı bankerlerin eline düşmüştü. ${ }^{118}$

Voyvodalar atandıktan sonra, Eflak ve Boğdan'da rahatsızlık unsuru olan suditlerden zararlı faaliyetler içerisinde bulunanların belirlenmesi ve sınır dışı edilmeleri için de çalışmalar

\footnotetext{
${ }^{110}$ DAB, HAT., nr. 45441; Ion Sandtu Sturdza Voyvoda tayn edildikten sonra bu anlamda çalışmaların başlatılmas talimat1 verilmiştir (DAB, A.DVN.DVE.d, nr. 80-4, s. 333-334).

${ }^{111}$ DAB, HAT., nr. 45376; HAT., nr. 45756 B; Sturdza boyarlık payeleri ile ilgili yaptığı düzenlemeleri İstanbul'a bildirdiği arzuhalinde, fenerli voyvodalar döneminde sayıları hizmetçileri ve yardımcılarıyla birlikte 40.000 'e ulaşan boyarları, 1821 isyanı sırasında Osmanlı askerinin yanında duran kimselerle değiştirdiğini ve sayılarını 14.000 'e düşürdügünü bildirmiştir. Boyarlık payesi alınan 24.000 kişiyi de vergi mükellefi yapmak suretiyle gelirlerin artırılacağını gerekçe göstererek yaptığı değişilikleri meşrulaştırmak istemişti (HAT., nr. 45376 C).

${ }^{112} \mathrm{DAB}, H A T$., nr. 45883.

${ }^{113}$ DAB, HAT., nr. 45892.

${ }^{114} \mathrm{DAB}, H A T .$, nr. 45884.

${ }^{115}$ Hükümde kastedilen tebaa Rumlar olmalıdır.

${ }^{116}$ DAB, A.DVN.DVE.d, nr. 80-4, s. 335.

${ }_{117}$ Theophilus C. Prousis, Lord Strangford at the Sublime Porte (1821): The Eastern Crisis, II, s. 204-205.

${ }^{118}$ Aleksandr Bitis, Russia and the Eastern Question, Army, Goverment, and Society 1815-1833, Oxford 2006, s. 434.
}

History Studies 
başlatılmıştır. ${ }^{119}$ Boğdan'da sudit statüsünde olduklarını iddia eden kimselerin bir listesinin çıkarılması, bu çalışmalar kapsamında istenmiştir. Suditlik iddiasında olan Avusturya, İngiltere ve sair ülkelerin tabiiyetindeki yabancıların kazalardaki en yakın ispravnike ${ }^{120}$ giderek isimlerini kaydettirmeleri ve kendilerine kefil bulamadıkları takdirde sınır dışı edilmeleri kararlaştırılmıştır. Yerli boyarların voyvoda naspedilmesiyle ilgili düzenlemenin gereği olarak, Boğdan kazalarında bulunan konsolos vekilliklerinin kaldırılması uygulamaya konulmuştur. Dışardan gelip sudit statüsünde ticaret yapmak isteyenlerin de belirli kontrollerden geçirilmesi istenmiştir. Ayrıca uygun görülmeyen suditlerin emlak ve arazi tasarrufunda bulunmamaları, Eflak ve Boğdan'la ilgili 1774 Küçük Kaynarca, 1792 Yaş Antlaşması ve sonraki yıllarda çıkarılan emirlere uygun olarak ${ }^{121}$ Avusturya konsolosluğuna iletilmiştir. ${ }^{122}$ Avusturya konsolosluğu bünyesindeki kimselerden gerçekte sudit olanların tespiti ve deftere kaydı için 4 kişilik bir komisyon kurulmuştu. ${ }^{123}$ Ayrıca, Boğdan kazalarına muteber boyarlar görevlendirilerek yukarıda belirtilen usul doğrultusunda, yabancı devletlerin himayesinde olan suditler belirlenmiş ${ }^{124}$ ve Boğdan'da yeni binalar inşa etmelerinin yasaklandiğı Avusturya konsolosu tarafından bölgedeki müstemenlere bildirilmişti. ${ }^{125}$ Tespit edebildiğimiz kadarıyla geride kalan ve "başı boş" olarak nitelendirilen 279 sudit sınır dışı edilmişti. ${ }^{126}$ Sınır dışı edilecek suditlerin bölgedeki gayrimenkullerini yerli boyarlara devretmeleri için altı ay süre tanınmış ${ }^{127}$ ve bu anlamda yapılan çalışmaların 1824 yılında tamamlandığ Nabi Efendi tarafından Bâbıâli’ye bildirilmiştir. ${ }^{128}$

Voyvodalar atandıktan sonra boyarların İstanbul'da sundukları taleplerden bir diğeri olan kilise ve manastırlar meselesi de önerdikleri şekilde çözüme kavuşturulmuştur. İsyan esnasında eşkıyaların gizlenmesine yardım eden ve manastırları adeta birer cephanelik haline getiren Rum keşişler görevlerinden uzaklaştırılarak bu kurumların ve vakıflarının idaresi Romenlere devredilmiştir. Eflak ve Boğdan'daki mabetlerin vakıf gelirlerinden Kudüs, Aynoroz ve Tûr-i Sînâ gibi kiliseler için ayrılan meblağın miktarı, Rum patriği tarafından Bâbıâli'ye bildirilecekti. Bâbıâli de bunu Memleketeyn kapı kethüdaları aracılığıyla voyvodalara ileterek bu anlamda maddi yükümlülüklerin yerine getirilmesine aracı olacak şekilde bir nizam verilmiştir. ${ }^{129} \mathrm{Bu}$ sayede manastır vakıflarından elde edilen gelirler Osmanlı Devleti tarafından kontrol altında tutularak başka yerlere aktarılması engellenmiş olacaktı.

\section{Sonuç}

Makalenin giriş kısmında Osmanlı Devleti'nin katılımcı ve esnek bir yönetim düzeni kurduğu vurgulanmıştı. Eflak ve Boğdan boyarlarının İstanbul'a gelerek taleplerini Babıali'ye iletmiş olmaları ve önerilerinin büyük ölçüde kabul edilerek uygulamaya konulması, Osmanlı

\footnotetext{
${ }^{119}$ DAB, A.DVN.DVE.d, nr. 80-4, s. 335-336.

${ }^{120}$ Atamaları voyvoda tarafından yapılan ispravniklerin görev süreleri bir yıldı. Vergilerin ve diğer primlerin toplanması, elde edilen gelirlerin voyvodanın hazinedarı olan Vestiar'a gönderilmesi ispravniklerin başlıca vazifeleriydi. İspravniklerin, beşlü zabitleriyle birlikte çarşı ve pazardaki düzeni tesis ettikleri anlaşılmaktadır. Giridli Hacı Ahmed, Eflak Coğrafyası, Topkapı Sarayı Müzesi Kütüphanesi, nr. 445, vr. 11a; William Wilkinson, An Account of the Principalities of Wallachia and Moldavia with Various Political Observations Relating to Them, London 1820, s. 58.

${ }^{121} \mathrm{DAB}, A . D V N . D V E . d$, nr. 80-4, s. 336.

122 DAB, HAT., nr. $45588 \mathrm{E}$.

${ }^{123}$ DAB, HAT., nr. 45588 L.

${ }^{124}$ DAB, HAT., nr. 47259.

${ }^{125} \mathrm{DAB}$, HAT., nr. 47263 A.

${ }^{126}$ Boğdan'dan sınır dışı edilen 279 suditin isimlerini havi liste için bkz. DAB, HAT., nr. 47259 A

${ }^{127} \mathrm{DAB}, H A T$., nr. 45877.

${ }^{128} \mathrm{DAB}$, HAT., nr. $45588 \mathrm{~K}$

129 DAB, HAT., nr. 45724; Rum keşişlerin kiliselerden uzaklaştırılmasıyla ilgili hüküm için bkz. DAB, A.DVN.DVE.d., nr. 82-6, s. 23.
} 
Devleti'nin kurduğu esnek ve katılımcı yönetim düzeni bağlamında iyi bir örnek niteliği taşımaktadır. Eflak ve Boğdan'da 1711'den önce olduğu gibi yeniden Romen voyvodalar hakim kılınmak suretiyle -her ne kadar kendileri Babıali nazarında "müfsid mizaç" olarak görülseler de- Romen boyarlar, merkezî Osmanlı yönetimiyle bütünleştirildiği gibi divan efendileri ve baş beşlü ağalarının yetki ve sorumluluk alanları genişletilerek Eflak ve Boğdan'daki Osmanlı nüfuzu daha da güçlendirildi. Memleketeyn'deki konsolos vekilleriyle ilgili düzenlemeler kapsamında bölgeye sonradan yerleşip servet, imtiyaz ve makam kazanmış yabancıların etkinliklerinin kısıtlanmaya çalışılması, bir anlamda Rusya ve Avrupa devletlerinin 1774 Küçük Kaynarca Antlaşması akabinde kurdukları rekabet alanını daraltmıştır. 1822 yılında ihya edilen kadim nizam, 1826 Akkerman Antlaşması kapsamında gözden geçirilmiştir. 1829 Edirne Antlaşması'nı müteakiben hazırlanan "Regulamentul Organic/Memleketeyn Nizamnamesi” adlı iç idare tüzüğüyle birlikte ise denge Rusya'nın lehine olacak şekilde ayarlanarak yeniden dizayn edilmiştir. ${ }^{130}$ Nihai tahlilde, Eflak ve Boğdan Beylikleri örneği özelinde Osmanlı devlet aklının ani ve plansız adımlarla değişikliğe gitmediği, tam aksine krizi başarılı bir şekilde yöneterek rasyonel ölçütler doğrultusunda çözüm ürettiği, yukarıda sunulan bulgular kapsamında öne sürülebilir.

\section{KAYNAKÇA}

1. Devlet Arşivleri Başkanlığı (DAB)

Bab-1 Asafi Amedi Kalemi Dosyaları (A. \{AMD.), nr.

47-11.

Bab-1 Asafi Divân-1 Hümâyûn Kalemi Dosyaları (A.\{DVN.), nr., 2509-13, 2509-13.

Bab-1 Asafi Mektubi Kalemi Dosyaları (A. \{MKT.), nr. 1583-61, 1582-4, 1582-47, 1583-4, 1583-16, 45-229, 1583-61.

Cevdet Hariciye (C.HR.), nr., 45-2239, 66-3283, 84-4195.

Cevdet Dahiliye (C.DH.), nr. 206-10272.

Düvel-i Ecnebiye Defterleri (A.DVN.DVE.d), nr. 77-1, nr. 80-4, nr. 81-5, nr. 82-6. Hatt-1 Hümâyûn (HAT.) nr.,

1561-24, 4544, 16805, 16805 A, 34867, 37877 D, 38777 A, 39910, 41038, 43077, 44927 E, 45341, 45361, $45365 \mathrm{E}, 45376,45376 \mathrm{C}, 45425$ A, $45425 \mathrm{~B}, 45441,45449$, 45449 A, 45454, 45454 C, 45454 E, 45454 D, 45454 G, 45454 F, 45454 H, 45454 B, $45465 \mathrm{G}, 45465 \mathrm{D}, 45510,45510 \mathrm{D}, 45510 \mathrm{C}, 45510 \mathrm{~A}, 45522,45528,45530$, 45546, 45547, 45547 A, 45560, 45587, 45588 E, 45588 L, 45588 K, 45591, $45605,45610,45611,45655,45666,45674$ B, 45679 A, 45695, 45723, 45724, 45766, 45780, 45792, 45853, 45877, 45879, 45883, 45884, 45886 A, 45892,

\footnotetext{
${ }^{130} 1826$ Akkerman Antlaşması ve devamında 1822 düzenlemelerinin gözden geçirilip revize edilme süreciyle ilgili detaylar için bkz. Feyzullah Uyanık, II. Mahmud Dönemi Osmanlı İdaresinde Eflak-Boğdan, (Trakya Üniversitesi Sosyal Bilimler Enstitüsü Basılmamış Doktora Tezi), Edirne 2018, s. 253 vd. 
45961, 45963 C, 47259, 47259 A, 47263 A, 8611, 5582, 5428, 45924 A, 50163, 459658.

Tahvil d., nr. 39.

2. Yazma Eserler

Giridli Hacı Ahmed, Eflak Coğrafyası, Topkapı Sarayı Müzesi Kütüphanesi, nr. 445.

Rumların Himayesi ve Eflak-Buğdan'ın Tahliyesi Hakkında, İstanbul Büyükşehir Belediyesi Atatürk Kitaplığı, nr. 61.

Yunan Fesâdına Dâir Bazı Fıkarât-ı Târîhiyye, Fatih Millet Kütüphanesi, Ali Emiri Tarih, nr. 669.

Melik Bey, Tarih-i Mora, Türk Tarih Kurumu Kütüphanesi Yazmaları (TTK), nr. Y/30.

3. Yayımlanmış Kaynaklar ve Telif Eserler

AHMED CEVDET PAŞA, Tarih-i Cevdet, XI-XII, İstanbul 1309.

AKTEPE, Münir, "Prut Seferi ile İlgilı Ba'zı Belgeler", Tarih Dergisi, XIV, İstanbul 1984, s. 19-54.

ANISIMOV, Evgenii V., The Reforms of Peter the Great: Progress Through Coercion in Russia, (translate John T. Alexander), M.E. Sharpe; Armonk, New York; London 1993.

ASLANTAŞ, Selim, Osmanlıda Sırp İsyanları 19. Yüzyılın Şafăğnda Balkanlar, İstanbul 2007.

BAĞIŞ, Ali İhsan, Osmanlı Ticaretinde Gayri Müslimler (Kapitülasyonlar, Avrupa Tüccarlarl, Beratlı Tüccarlar, Hayriye Tüccarları 1750-1839), Ankara 1983.

BEYDİLLI, Kemal, Büyük Friedrich ve Osmanlılar XVIII. Yüzyılda Osmanl-Prusya Munasebetleri, İstanbul 1985.

BITIS, Aleksandr, Russia and the Eastern Question, Army, Goverment, and Society 1815 1833, Oxford 2006.

CASTELlAN, Georges, Balkanların Tarihi (14.-20. Yüzyıl), (terc. Ayşegül YaramanBaşbuğu), İstanbul 1993.

DVOİCHENKO-MARKOV, Demetrius, "Russia and the First Accredited Diplomat in the Danubian Principalities, 1779-1808", Études Slaves et Est-Européennes, (Autumn-Winter) 1963, s. 200-229.

EMECEN, Feridun M., “Osmanlıların Tuna'nın Kuzeyine Yönelik İlgileri XVI. Asırda Erdel Örneği”, Osmanlı Klasik Çağında Siyaset, İstanbul 2009, s. 221-238. , "Haracgüzar", DIA, XVI, İstanbul 1997, s. 90-92.

ERMAHIŞ, Neslihan, Osmanlı Imparatorluğu'nda Bir Kolluk Kuvvet: Kır Serdarlığı, Cumhuriyet Üniversitesi Sosyal Bilimler Enstitüsü, (Basılmamış) Yüksek Lisans Tezi, Sivas 2018.

FLORESCU, Radu R., The Struggle Aganist Russia in the Romanian Principalities 1821 1854, Iaşi 1997. 
,"The Fanariot Regime in the Danubian Principalities", Balkan Studies, IX, 1968, s. 301-318.

FRANGOS, George Demetrios, The Philike Etaireia, 1814-1821: A Social and Historical Analysis, Colombia Universty, (Unpublished) Phd Thesis, 1971.

FRARY, Lucien J., "Russian Consuls and the Greek War of Independence (1821-31)" Mediterranean Historical Review, XXVIII/1, (2013), s. 46-65.

GÖKBİLGIN, Tayyib, "XVI. Asır Ortalarında Osmanlı Devletinin Tuna Havzası ve Akdeniz Siyasetleri, Bunlar Arasındaki Alâka ve İrtibat, Muhtelif Veçheleri”, Ankara Üniversitesi Dil ve Tarih-Coğrafya Fakültesi Dergisi, XIII/4, Ankara 1955, s. 63-77.

GUBOĞLU, Mihail , "Eflak ve Boğdan Voyvodalarının Bab-1 Ali ile Münasebetleri”, Belgelerle Türk Tarihi Dergisi, 1, Ankara 1967, s. 61-67. , "Kanuni Sultan Süleyman'ın Boğdan Seferi ve Zaferi (1538 M. 945 H.)", Belleten (ayrı basım), L/198, Ankara 1987, s. 728-805.

HITCHENS, Keith, The Romanians 1774-1866, New York 2011.

HITCHINS, Keith, A Concise History of Romania, New York 2014.

İNALCIK, Halil , "Dār al-“Ahd”, The Encyclopaedia of Islam (EI), II, Leiden: E. J. Brill, 1991, s. 116.

JELAVICH, Barbara, Russia and the Formation of Romanian National State 1821-1878, Cambridge 1984.

JORGA, Nikolae, Osmanlı Imparatorluğu Tarihi (1774-1912), V, (terc. Nilüfer Epçeli), İstanbul 2009.

KILIÇ, Musa, "1821 Rum İsyanı Sonrasında Fenerlilerin Bürokraside Yeniden İstihdamlarında İki Öncü İsim: İstefanaki Vogorides ve Nikolas Aristarki”, Musa Çadırcıya Armağan/Studies Presented in Honour of Musa Çadırcı, Ankara 2012, s. $275-284$.

KÖSE, Osman, 1774 Küçük Kaynarca Andlaşması, Ankara 2006.

"Balkanlarda Rus Konsolosluklarının Kuruluşu ve Faaliyetleri", Turkish Studies/Türkoloji Dergisi, I/2, Erzincan 2006, s. 153-171.

MAYUZIMİ, Akitsu, "The Establishment of the Russian Consulates in the Danubian Principalities in the 1780s and the Ottoman Empire", Turkey\&Romania: A History of Partnership and Collaboration in The Balkans, (ed. Florentina Nitu, Cosmin Ionita, Metin Ünver...), İstanbul 2016, s. 287-295.

Mehmed Şevki, "Memleketeyn-i Müctemiateyn: Eflak-Boğdan”, Mecmû‘a-i Fünûn, IV/35, İstanbul 1283, s. 56-69.

MEHMET MANSUR, Rum Fetreti-Yunanistan İsyân ve Teşekkülü-(Tahlil ve Transkripsiyon), (haz. Volkan Marttin), Osmangazi Üniversitesi Sosyal Bilimler Enstitüsü, (Basılmamış) Yüksek Lisans Tezi, Eskişehir 2004.

MEHMET, Mustafa Ali, "Romen Vekâyinâmelerine Göre Baltacı Mehmed Paşa'nın Prut Seferi (1711)", Türk Kültürü Araştırmaları İbrahim Kafesoğlu'nun Hatırasına Armăgan, XXIIII/1-2, Ankara 1985, s. 427-436. 
MIHAIL, Bogdan, "The Russian Modernist Influences in the Danubian Principalities", From Kaftan to Redingote: The Romanian World from Exotism to Modernism (17th-20th Centuries), (Coordinators: Iolanda Thighiliu, Marian Cojoc, Daniel Flaut), Târgovişte 2011, s. 83-86.

MOURAVIEFF, Boris, Deli Petro'nun Vasiyetnamesi, (çev, Refik Özdek), İstanbul 1966.

MÜTERCIM AHMED ASIM EFENDİ, Âstm Efendi Tarihi (Osmanlı Tarihi 1218 1224/1804-1809 İnceleme-Metin), (haz. Ziya Y1lmazer), I, İstanbul 2015.

ÖRENÇ, Ali Fuat, Balkanlarda İlk Dram Unuttuğumuz Mora Türkleri ve Eyaletten Bağımsızlı̆̆a Yunanistan, İstanbul 2011.

ÖZCAN, Abdülkadir, “İane”, DIA, XIX, İstanbul 1999, s. 229. , "Karlofça Antlaşması", DİA, XXIV, İstanbul 2001, s. 504-507.

ÖZEL, Ahmet, "Dârüssulh", DİA, IX, İstanbul 1994, s. 5-6.

ÖZKAYA, Yücel, "1821 Yunan (Eflak-Buğdan) İsyanları ve Avrupalıların İsyan Karşısındaki Tutumları", Üçüncü Askeri Tarih Semineri Bildiriler; Tarih Boyunca Türk-Yunan Illişkileri (20 Temmuz 1974'e Kadar), Ankara 1986, s. 114-132.

PAKALIN, Mehmet Zeki, "Rikâbiyye", Osmanlı Tarih Terimleri ve Deyimleri Sözlüğü, III, İstanbul 1993, s. 46.

PANAGIOTOPOULOS, Vasilis, "The Filiki Eteria (Society of Friends) Organizational Preconditions of National War of Indipendence", The Greek Revolution of 1821: A European Event, (ed. Petros Pizanias), İstanbul 2011, s. 101-126.

PANAITE, Viorel , "Notes on the Islamic-Ottoman Law of Peace", Revue des Études sud-est Européennes, XLI/1-4, Bucureşti 2003, s. 191-206.

" "Osmanlı Barışı Sisteminde Haraç veren Voyvodalıklar: Eflak ve Boğdan Meselesi”, Kemal Karpat'a Armağan: Karpat Koca Bir Çınar, (der. Kaan Durukan, Robert W. Zens, Akile Zorlu Durukan), (çev. İlknur Güzel), İstanbul 2014, s. 34-70.

PHILLIOU, Christine M., Biography of an Empire: Governing Ottomans in an Age of Revolution, London 2011.

PROUSIS, Theophilus C., Lord Strangford at the Sublime Porte (1821): The Eastern Crisis, II, İstanbul 2012.

Lord Strangford at the Sublime Porte (1821): The Eastern Crisis, I, İstanbul 2010.

SETON-WATSON, R. W., A History of the Roumanians from Roman Times to the Completion of Unity, Archon Books 1963.

SÖZEN, Zeynep, Fenerli Beyler 110 Yılın Öyküsü (1711-1821), İstanbul 2000.

STRIHAN, Petre, "Divan-Effendi în Ţara Românească şi Moldova în secolele XVIIXIX", Studii Revista de Istorie, XXI/5, Bucuresti 1968, s. 881-896.

ŞÂNÎ-ZÂDE MEHMED 'ATÂ’ULLAH EFENDİ, Şânî-zâde Târihi (1223-1237/18081821), II, İstanbul 2008 
TERTECEL, Adrian, "Eflâk Prensi Konstantin Brinkoveanu'nun Rus Çarı Deli Petro'ya 1698'de Gönderdiği Bir Mektupta Bulunan Osmanlı İmparatorluğuna Karş1 Müşterek Bir Rus-Romen Askerî Harekâtının Plânı”, Türk Dünyası Tarih Dergisi, Say1 118, İstanbul (Ekim) 1996, s. 7-14.

TOGAN, Zeki Velidi, Umumi Türk Tarihine Giriş, İstanbul 1981.

UYANIK, Feyzullah, II. Mahmud Dönemi Osmanlı İdaresinde Eflak-Boğdan, (Trakya Üniversitesi Sosyal Bilimler Enstitüsü Basılmamış Doktora Tezi), Edirne 2018.

YAŞAR, Filiz, "Yunan İsyanında Osmanlının Rumeli'de ve Anadolu'da Aldığı Güvenlik Önlemleri: Tedâbîr-i Osmâniyye", Hacettepe Üniversitesi Edebiyat Fakültesi Dergisi, XXXII/2, Ankara 2015, s. 277-297.

YENIDÜNYA GÜRGEN, Süheyla, Devletin Kahyası Sultanın Efendisi Mehmed Said Halet Efendi, İstanbul 2018.

YILMAZ, Fehmi, Osmanlı Tarih Sözlüğ̈̈, İstanbul 2010, s. 262.

WILKINSON, William, An Account of the Principalities of Wallachia and Moldavia with Various Political Observations Relating to Them, London 1820.

STOİCESCU, Nicolae, Sfatul Domnesc şi marii Dregători din Țara Românească şi Moldova (sec. XIV-XV), București 1968.

TREPTOR, Kurt W., Marcel Popa, Historical Dictioanry of Romania, London 2000, s. $88-90$. 